\title{
Cladistics
}

\section{Phylogenetic relationships of subfamilies and circumscription of tribes in the family Hesperiidae (Lepidoptera: Hesperioidea)}

\author{
Andrew D. Warren ${ }^{\mathrm{a}, \mathrm{b}, *}$, Joshua R. Ogawa ${ }^{\mathrm{c}}$ and Andrew V. Z. Brower ${ }^{\mathrm{c}}$ \\ ${ }^{a}$ McGuire Center for Lepidoptera and Biodiversity, Florida Museum of Natural History, University of Florida, SW 34th Street and Hull Road, PO Box \\ 112710, Gainesville, FL 32611-2710, USA; ${ }^{b}$ Museo de Zoología, Departamento de Biología Evolutiva, Facultad de Ciencias, Universidad Nacional \\ Autónoma de México, Apdo. Postal 70-399, México DF 04510, México; ${ }^{c}$ Department of Biology, Middle Tennessee State University, Murfreesboro, TN \\ 37132, USA
}

Accepted 10 January 2008

\begin{abstract}
A comprehensive tribal-level classification for the world's subfamilies of Hesperiidae, the skipper butterflies, is proposed for the first time. Phylogenetic relationships between tribes and subfamilies are inferred using DNA sequence data from three gene regions (cytochrome oxidase subunit I-subunit II, elongation factor-1 $\alpha$ and wingless). Monophyly of the family is strongly supported, as are some of the traditionally recognized subfamilies, with the following relationships: (Coeliadinae + ("Pyrginae" + (Heteropterinae $+($ Trapezitinae + Hesperiinae $)))$ ). The subfamily Pyrginae of contemporary authors was recovered as a paraphyletic grade of taxa. The formerly recognized subfamily Pyrrhopyginae, although monophyletic, is downgraded to a tribe of the "Pyrginae". The former subfamily Megathyminae is an infra-tribal group of the Hesperiinae. The Australian endemic Euschemon rafflesia is a hesperiid, possibly related to "Pyrginae" (Eudamini). Most of the traditionally recognized groups and subgroups of genera currently employed to partition the subfamilies of the Hesperiidae are not monophyletic. We recognize eight pyrgine and six hesperiine tribes, including the new tribe Moncini.
\end{abstract}

(c) The Willi Hennig Society 2008.

The family Hesperiidae, commonly known as "skippers" or "skipper butterflies", includes around 4000 species (Bridges, 1993), currently distributed among 567 genera (Appendix 1). Compared with our understanding of all other butterfly families, our knowledge of hesperiid geographical distributions, immature stages, larval foodplants, and phylogenetic relationships remains poor (Warren, 2000; Wahlberg et al., 2005b). Furthermore, there is no consensus on the taxonomic status of various skipper groups, or on the overall limits of the family. For example, the Megathyminae (or "giant skippers") have variously been considered to represent a family (e.g. Freeman, 1969b), subfamily (e.g. Mielke, 2004, 2005), or a specialized group of genera within the subfamily Hesperiinae (e.g. Ackery et al., 1999). Similarly, the Australian endemic Euschemon

\footnotetext{
*Corresponding author:

E-mail address: hesperioidea@yahoo.com
}

rafflesia, which, like no other butterfly, possesses a frenulum and retinaculum in the male, has often been considered to be a "moth" (e.g. Butler, 1870; Scudder, 1875; Watson, 1893), or to represent a family-group taxon within the Hesperiidae (e.g. Mabille, 1876; Janse, 1925; Voss, 1952), while some authors have placed it in the Pyrginae (e.g. Evans, 1949).

About 130 years ago, Adolph Speyer (1877) wrote, "A systematic treatment of the Hesperidae [sic] is a very difficult task, and, according to my opinion, can only be accomplished with reference to the whole known family, in all parts of the world..." Despite these sage words, the most recent efforts to reconcile the hesperiid fauna of the world in a uniform systematic arrangement were attempted over 100 years ago (Watson, 1893; Mabille, 1903-1904). All systematic treatments of the Hesperiidae since Mabille (1903-1904) have been regional in nature, save the cosmopolitan exemplar study by Voss (1952), which included a limited sample of 54 species. 
William Harry Evans' (1937, 1949, 1951, 1952, 1953, 1955) monumental series of monographs represents the most recent revision of the world's fauna of Hesperiidae, although he proposed somewhat independent classification schemes for each of the world's regions. Evans arranged phenotypically similar genera into informal groups to aid in their identification, but rarely hypothesized relationships among groups in the same subfamily distributed in different parts of the world. Although there have been some modifications to Evans' classification (see Appendix 1), his taxonomic system remains largely intact in current treatments of the group. As a result, Hesperiidae is the only family of butterflies without a widely accepted tribal-level classification for all of the major subfamilies (Ackery et al., 1999; Lamas, 2004; Mielke, 2005). As noted by Voss (1952), the skippers' "remarkable uniformity of structure leaves us with so little upon which to base sound distinctions that we often are forced to consider significant any trivial character that appears to be a fairly consistent criterion to characterize a group". Indeed, few morphological synapomorphies have been identified that can readily characterize any subfamily of skippers (Ackery et al., 1999), and there is no general consensus on the composition of or relationships among the various subfamilies (de Jong et al., 1996).

Considering the recent progress in understanding the higher-level systematics of other groups of Lepidoptera (e.g. Weller et al., 1994; Brower, 2000; Regier et al., 2000, 2002; Wiegmann et al., 2000; Caterino et al., 2001; Bucheli and Wenzel, 2005; Wahlberg et al., 2005a,b; Braby et al., 2006; Brower et al., 2006; Peña et al., 2006), it is clear that molecular characters can be useful in delineating higher-level taxa and determining relationships. We agree with Larsen (2005), who noted for the Hesperiidae, "A molecular study to assist in the redefinition of subfamilies, tribes, and genera - and not least the relationships within the family worldwide would be a worthwhile exercise".

In the present study we test the monophyly of the most recent circumscriptions of the subfamilies of the Hesperiidae, as well as Evans' generic groupings within each subfamily. We endeavour to delineate tribes within the major subfamilies, and determine relationships among tribes and subfamilies of the Hesperiidae. We also aim to gain preliminary insights into certain historically controversial genus-level relationships. Hesperiidae is currently divided into seven subfamilies, namely Coeliadinae, Pyrrhopyginae, Pyrginae, Heteropterinae, Trapezitinae, Hesperiinae and Megathyminae (see Table 1), which include a total of 567 genera (see Appendix 1). Some recent authors (e.g. Atkins, 2005) recognize an eighth subfamily, Euschemoninae, while other authors treat the Heteropterinae (e.g. Bridges, 1993; Pyle, 2002) or Megathyminae (e.g. Ackery et al., 1999; Opler and Warren, 2002) as subordinate taxa of the Hesperiinae. Evans divided the Pyrrhopyginae, Pyrginae and Hesperiinae into a total of 28 generic groups, a few of which have since been modified and given formal recognition at the tribal or subfamily level (e.g. Higgins, 1976; Mielke, 2001). Evans further divided nine of his generic groups into 38 subgroups, for a total of 58 suprageneric taxa. We have sampled one or more members from all but three of Evans' groups and subgroups, and two or more members from all but ten of these (excluding monotypic subgroups), allowing us to make a preliminary assessment of the monophyly of most of Evans' suprageneric hypotheses (see Appendix 1), and to evaluate the naturalness of these groups as a basis for a phylogenetic tribal classification. Our hypothesis of relationships is based upon DNA sequences from three gene regions: a contiguous region of mitochondrial cytochrome oxidase subunits $I$ and II (COI-COII), and nuclear elongation factor- $1 \alpha$ $(E F-1 \alpha)$ and wingless.

\section{Materials and methods}

\section{Taxon sampling}

Adult butterflies were sampled with aerial nets in the field, by the authors and various colleagues. Specimens were preserved in $85-100 \%$ ethanol, with wings removed prior to submersion, or were preserved dry, in glassine envelopes. The species sampled and their collection localities are listed in Appendix 2. A total of 209 species in 198 genera are included in the combined analysis of three genes, discussed below, representing about $35 \%$ of the world's skipper genera (sensu Ackery et al., 1999; Mielke, 2001, 2004, 2005; see Table 1, Appendix 1). Partial (two gene segments) or complete data were obtained for 22 additional genera and species (marked with an asterisk in Appendix 1), which were not included in the final combined analysis but were included in alternative analyses and are discussed below. Sequences for all taxa are new, except for outgroups and five skipper species, which were published in Wahlberg et al. (2005a). Five outgroup species (see Appendix 2) were selected, one from each family of the Papilionoidea, the putative sister clade to the Hesperioidea (Wahlberg et al., 2005a). Sequences for the outgroup species were obtained from GenBank.

\section{Laboratory protocols}

Total genomic DNA was extracted from individual butterflies, by using a standard phenol-chloroform extraction protocol (Brower, 1994, 2000) or Qiagen's DNEasy extraction kits (Qiagen, Venlo, the Netherlands) according to the manufacturer's instructions. We extracted DNA from the thorax of specimens preserved in ethanol, or from two legs of dried butterflies. Vouchers consist of vials of DNA suspended in 
Table 1

Traditional and revised family-level classifications of Hesperiidae. Left column represents the classification proposed by Evans and subsequent authors, as detailed in Appendix 1. Right column represents the classification proposed in this paper. Dashes prior to names indicate the following taxonomic status: $1=$ family-level name; 2 =subfamily-level names; $3=$ tribal names; $4=$ subtribal names; $5=$ subjective junior synonyms; $6=$ unavailable names

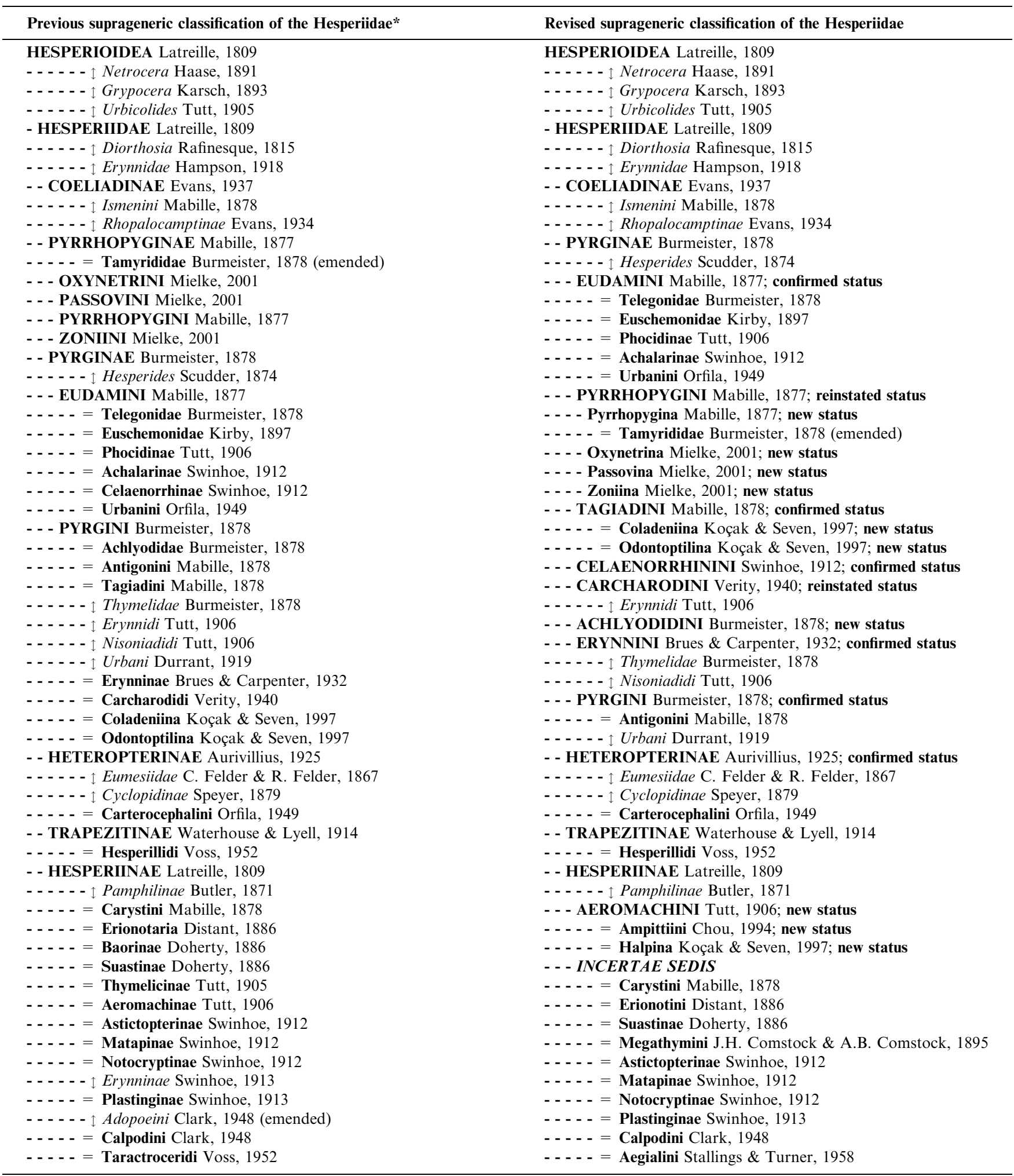


Table 1

Continued

\begin{tabular}{|c|c|}
\hline Previous suprageneric classification of the Hesperiidae* & Revised suprageneric classification of the Hesperiidae \\
\hline 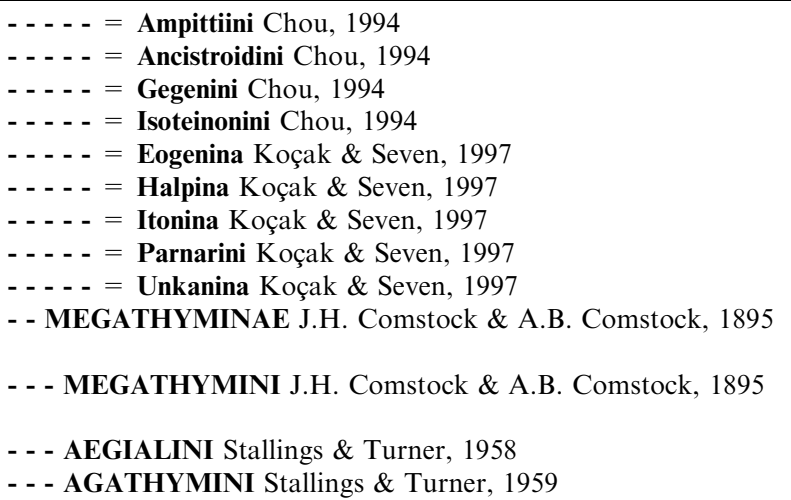 & 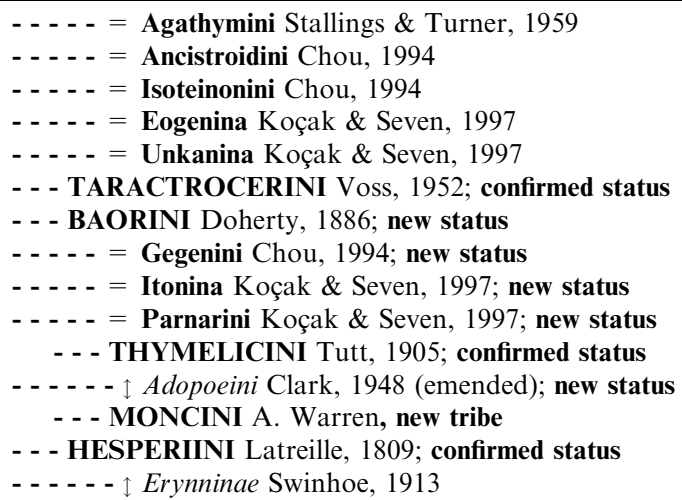 \\
\hline
\end{tabular}

*This synonymy is based on the arrangement detailed in Appendix 1.

$\uparrow=$ unavailable name. There are at least four family group names formed from the genus Erynnis, but only one of these is based on the genus properly identified. As dictated by Code articles 41 and 65.2.1 (ICZN, 1999), the case should be referred to the Commission for a ruling. In the meantime, we treat these names as if the Commission has ruled to suppress all but the one properly proposed name (Erynninae Brues and Carpenter, 1932).

HPLC-grade water (final elution volume between 50 and $500 \mu \mathrm{L}$, depending on amount of starting tissues), frozen at $-20{ }^{\circ} \mathrm{C}$, and corresponding wings and body parts (usually minus the thorax) stored in glassine envelopes. DNA and residual morphological materials will be permanently deposited in public institutions, as indicated in Appendix 2.

For each specimen, we amplified and sequenced a 943-bp fragment spanning the $3^{\prime}$ end of COI, the tRNAleu and the $5^{\prime}$ end of COII, $739 \mathrm{bp}$ of $E F-1 \alpha$ and $403 \mathrm{bp}$ of the wingless gene (although in a few cases sequences for different genes were obtained from two specimens, as indicated in Appendix 2). Skipper-specific primers for COI-COII were developed (Gary and Susan, see Table 2), after obtaining preliminary sequences from primers listed in Brower and Jeansonne (2004) and Brower et al. (2006). Primers for $E F-1 \alpha$ were taken from
Cho et al. (1995) and Monteiro and Pierce (2001), and for wingless from Brower and DeSalle (1998); all primers used in this study are listed in Table 2. PCR amplifications were performed in a 50- or $100-\mu 1$ reaction volume, on a Peltier thermal cycler (PTC-100, MJ Research, c/o Biorad, Hercules, CA, USA). Amplifications conducted in a $50-\mu \mathrm{L}$ reaction volume included $3 \mu \mathrm{L}$ of template, $5 \mu \mathrm{L}$ of $10 \times$ buffer $(0.1$ м Tris $-\mathrm{HCl}, 0.1 \mathrm{M} \mathrm{KCl}, 1 \%$ Triton X-100, $\mathrm{pH} 8.3$ ), $5 \mu \mathrm{L}$ of $25 \mu \mathrm{M} \mathrm{MgCl}_{2}, 1 \mu \mathrm{L}$ of $10 \mu \mathrm{M}$ dNTPs, $2 \mu \mathrm{L}$ of each primer $(10 \mu \mathrm{M}), 0.3 \mu \mathrm{L} \mathrm{Taq}$ polymerase, and $31.7 \mu \mathrm{L}$ distilled water. Amplifications conducted in a $100-\mu \mathrm{L}$ reaction volume included $1 \mu \mathrm{L}$ of template, $10 \mu \mathrm{L}$ of $10 \times$ buffer, $15 \mu \mathrm{L}$ of $25 \mu \mathrm{M} \mathrm{MgCl}_{2}$, $2 \mu \mathrm{L}$ of $10 \mu \mathrm{m}$ dNTPs, $2 \mu \mathrm{L}$ of each primer $(10 \mu \mathrm{m})$, $0.2 \mu \mathrm{L} \mathrm{Taq}$ polymerase, and $69 \mu \mathrm{L}$ distilled water. The cycling profile for $\mathrm{COI}$-COII and wingless was $4 \mathrm{~min}$ at $92{ }^{\circ} \mathrm{C}$, and 40 cycles of $1 \mathrm{~min}$ at $94{ }^{\circ} \mathrm{C}, 0.5$ or $1 \mathrm{~min}$ at

Table 2

Oligonucleotide primers used in this study

\begin{tabular}{|c|c|c|c|c|}
\hline Name & Gene & Strand & Primer sequence & Position* \\
\hline LepWG1 & wingless & $\mathrm{S}$ & 5'-GARTGYAARTGYCAYGGYATGTCTGG-3' & $1111-1136$ \\
\hline LepWG2 & wingless & A & 5'-ACTICGCRCACCARTGGAATGTRCA-3' & $1750-1775$ \\
\hline Rudy & COI & $\mathrm{S}$ & 5'-GAAGTTTATATTTTAATTTTACCGGG-3' & $2191-2217$ \\
\hline Gary & COI & $\mathrm{S}$ & 5'-TAGGAATAATTTATGCMATAATAGC-3' & $2276-2301$ \\
\hline Susan & COI & A & 5'-TTGTTGTTCTAATARAAATCG-3' & $3242-3263$ \\
\hline George I & COI & $\mathrm{S}$ & 5'-ATACCTCGACGTTATTCAGA-3' & $2772-2792$ \\
\hline Tipper & $E F-1 \alpha$ & A & 5'-ACAGCVACKGTYTGYCTCATRTC-3' & $3344-3367$ \\
\hline Gennifer & $E F-1 \alpha$ & A & 5'-CGCACGGCAAAACGACCGAGRGG-3' & $3320-3342$ \\
\hline
\end{tabular}

*Locations of the wingless primers in the Drosophila melanogaster wingless sequence (Rijsewijk et al., 1987); of the COI-COII primers in the Drosophila yakuba mitochondrial genome sequence (Clary and Wolstenholme, 1985), and the Ef-1 $\alpha$ primers in the Drosophila melanogaster sequence as reported by Cho et al. (1995). 
$46{ }^{\circ} \mathrm{C}$, and $2 \mathrm{~min}$ at $72{ }^{\circ} \mathrm{C}$, and that for $E F-1 \alpha$ was 2 min at $94{ }^{\circ} \mathrm{C}$, and 32 cycles of 1 min at $94{ }^{\circ} \mathrm{C}, 1 \mathrm{~min}$ at $60{ }^{\circ} \mathrm{C}$, and $1.5 \mathrm{~min}$ at $72{ }^{\circ} \mathrm{C}$, followed by $10 \mathrm{~min}$ at $72{ }^{\circ} \mathrm{C}$

Amplified DNA fragments were cleaned with silica beads (Bio 101, Qbiogene, Irvine, CA, USA), or with Qiaquick PCR purification kits (Qiagen). Cleaned PCR products were cycle sequenced using ABI Prism or Big Dye kits (Applied Biosystems, Foster City, CA, USA), in a PTC-100, with the same primers as used for PCR. Recommended reaction conditions were used, along with the profile of 60 cycles of $0.5 \mathrm{~min}$ at $96^{\circ} \mathrm{C}$, $0.25 \mathrm{~min}$ at $50{ }^{\circ} \mathrm{C}$, and $4 \mathrm{~min}$ at $60^{\circ} \mathrm{C}$. Single-stranded products were cleaned using ethanol and sodium acetate precipitation, and run on an ABI 373A or 377 automated sequencer or outsourced to Macrogen (Seoul, South Korea). All sequences were generated in both directions. Automated sequence outputs were edited manually and aligned by eye. Other than some minor length heterogeneity at the beginning and end of the tRNA and a single one-codon deletion in wingless (present in two taxa), there was no ambiguity in the alignment. Heterozygous positions in the nuclear genes (where simultaneous chromatogram peaks for two nucleotides appeared almost or exactly equal) were coded according to the IUPAC ambiguity codes. The aligned data matrix is available on the web at http:// www.treebase.org. Individual sequences have been submitted to GenBank (accession codes given in Appendix 2).

\section{Phylogenetic analysis}

Data were concatenated and analysed as a single matrix under the parsimony criterion. Gaps were scored as missing; all characters and transformations were weighted equally. We searched for the most parsimonious cladograms from the unordered and equally weighted data matrix consisting of 215 taxa. Trees were rooted with Papilio, and other non-hesperiid taxa were included in the ingroup to test the monophyly of Hesperiidae. The parsimony analyses were performed in PAUP* 4.0b 10 (Swofford, 2002) using the parsimony ratchet (Nixon, 1999) as implemented in PAUP* by PAUPRat (Sikes and Lewis, 2001). The general ratchet analysis conditions were as follows: seed $=0$, nreps $=200$, wtmode $=$ uniform. The percentage of characters perturbed during each iteration (pct) varied between 5, 10 and $15 \%$. The search was repeated five times for each level of character perturbation, yielding a total of 15 independent ratchet searches. The maximumparsiomiony (MP) tree length was corroborated in NONA 2.0 (Goloboff, 1999) using similar parameters as the PAUP* tree searches. In addition, we explored the structure of the data with separate analyses of each gene region, using heuristic searches with 1000 random addition replicates using tree bisection-reconnection (TBR) branch swapping with a single tree held during each step.

In the combined analysis, we evaluated character support and congruence among partitions for the clades in the strict consensus of the MP trees using branch support (BS: Bremer, 1988, 1994), partitioned branch support (PBS: Baker and DeSalle, 1997; Gatesy et al., 1999 ) and the partition congruence index (PCI: Brower, 2006b; see also Brower et al., 2006). Fractional PBS values were rounded to two decimal places. Due to the computationally intensive structure of the data set, BS values were calculated in PAUP* using PAUPRatgenerated batch files that were modified to search anticonstraint trees generated from the MP tree set using TreeRot v.2. (Sorenson, 1999). Although tedious to set up by hand, the use of the parsimony ratchet to search for anti-constraint tree lengths consistently found shorter trees (resulting in lower BS values) than searches using standard PAUP* heuristic strategies. As in other recent studies (e.g. Wahlberg and Nylin, 2003; Wahlberg et al., $2003,2005 b$ ), we refer to the support values as giving weak, moderate, good or strong support when discussing our results. We define 'weak support' as BS values between 1 and 2, 'moderate support' as BS values between 3 and 5, 'good support' as values between 6 and 10, and 'strong support' as values of 11 and greater. We endorse BS values over bootstrap values as they are a parameter of the data, rather than an estimate of tree stability based on pseudoreplicated subsamples of the data, and because they have no upper bound (Brower, 2006b).

\section{Results and discussion}

\section{Characteristics of the data set}

The total combined data consist of $2086 \mathrm{bp}, 913$ of which are invariant and 890 of which are parsimonyinformative. Combining the three data sets in simultaneous parsimony analysis yields 90 trees of 19,123 steps $(\mathrm{CI}=0.091, \mathrm{RI}=0.422)$, the strict consensus of which is shown in Figs 1 and 2. Up to 35 positions were coded as gaps in some taxa, including one gap in the wingless data set and three gaps in the COI-COII data set; all of these were easily detected when aligning by eye, as flanking regions were conserved. A few sequences are incomplete and 11 taxa are missing wingless sequences (see Appendix 2). Basic statistics for the three gene regions are shown in Tables 3 and 4.

In order to investigate incongruence (Mickevich and Farris, 1981; Farris et al., 1994), we conducted separate analyses of the three gene regions. Overall, the phylogenetic signal of wingless strongly conflicts with the other two gene regions (Table 3). Although wingless 


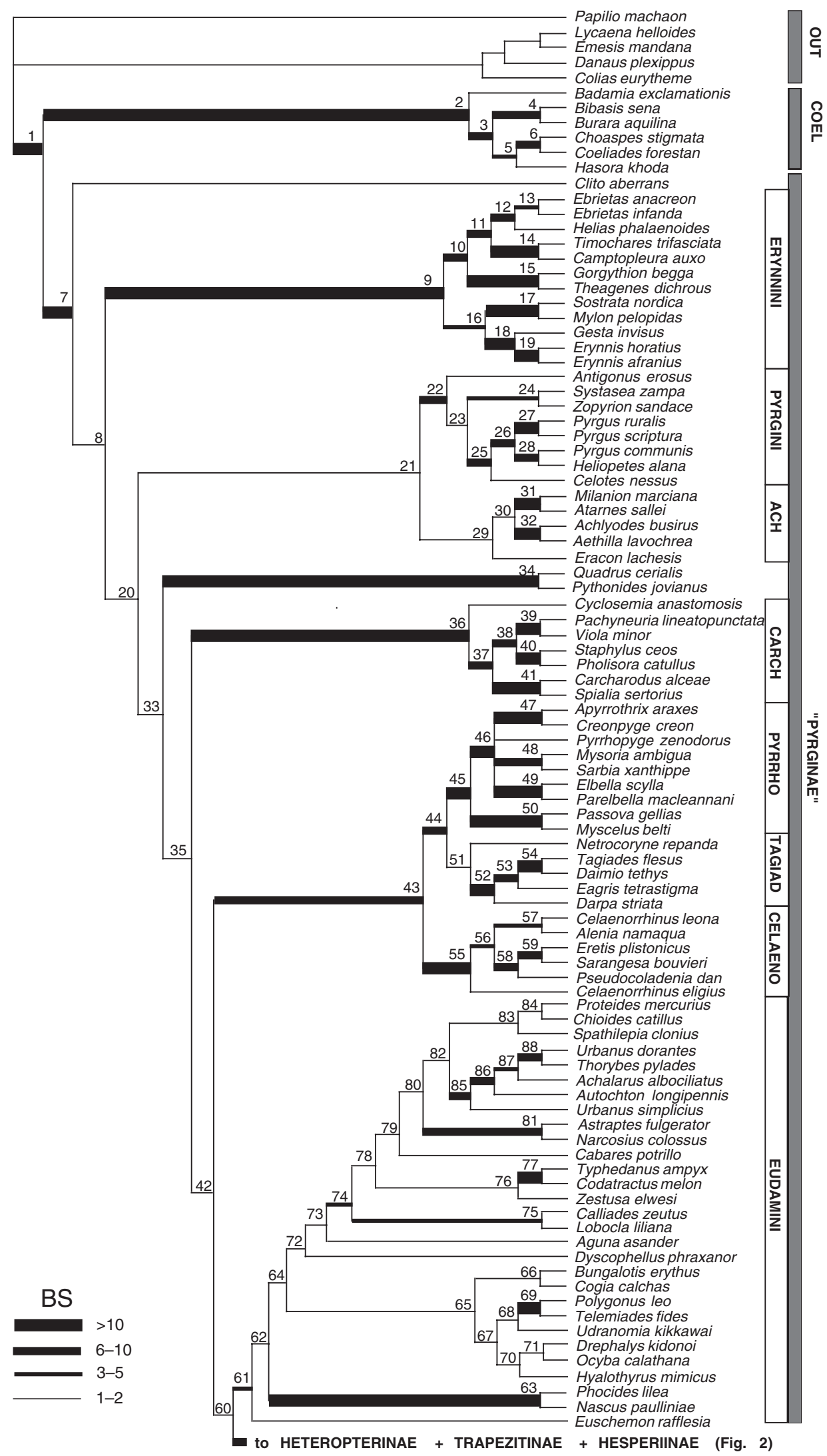


Fig. 1. Strict consensus of 90 most-parsimonious trees from the combined data set of all three genes. Length 19123 steps $(\mathrm{CI}=0.091$; RI $=0.422)$. Clade numbers are indicated above branches. Corresponding branch support values, partitioned branch support values and partition congruence indices are given in Table 4. Branch width relates to BS support values, as indicated in the legend in the lower left corner. Taxon names are listed in Appendix 2, together with voucher information. OUT $=$ outgroup taxa, COEL $=$ Coeliadinae, PYRRHO $=$ Pyrrhopygini, TAGIAD $=$ Tagiadini, CELAENO = Celaenorrhinini, $\mathrm{ACH}=$ Achlyodidini, $\mathrm{CARCH}=$ Carcharodini.

provides little positive BS support for any of the internal nodes (Table 4), the gene region may be informative at higher taxonomic levels: excluding wingless from the analyses resulted in a paraphyletic ingroup (results not shown). Of the 186 resolved ingroup branches, COICOII provides positive support to 139 and contradicts 47, EF- $1 \alpha$ supports 147 and contradicts 39, and wingless supports 51 and contradicts 135 (11 taxa are missing the wingless sequence). Seventeen branches are supported by all three gene regions, 103 supported only by $C O I-C O I I$ $+E F-1 \alpha, 14$ only by COI-COII + wingless, 18 only by EF-1 $\alpha+$ wingless, 23 by COI-COII only, 25 by EF-1 $\alpha$ only, and two by wingless only. Thus, although COI$C O I I$ and EF- $1 \alpha$ appear to provide most of the phylogenetically informative characters, no single gene region drives the topology of the combined hypothesis of relationships, which is different from any of the trees implied by single genes analysed separately (results from separate analyses not shown).

The classification of Hesperiidae discussed below is based on the results of the combined cladistic analysis. The nomenclatorial philosophy we employ is that all named taxa should be monophyletic, and that taxa meeting this criterion should bear names and ranks associated with them in the historical literature to the greatest degree possible. BS values for individual clades are indicated below (also see Table 4). In the text below, numbers in parentheses after the names of taxa refer to the numbered clades in Figs 1 and 2.

\section{Subfamily-level relationships}

This is the first comprehensive phylogenetic analysis of relationships within the family Hesperiidae. Previous phylogenetic studies of the family have been limited by insufficient taxon sampling, either lacking sufficient taxa for adequate resolution (e.g. de Jong et al., 1996; Warren, 2004), or including taxa sampled on a regional basis only (Chiba et al., 2001), and therefore lacking major sections of diversity present in the family. Other family-level studies of the Hesperiidae have not employed a cladistic methodology, and/or have scored and analysed characters in an ambiguous way (Voss, 1952; Scott, 1985; Scott and Wright, 1990; Atkins, 2005). In our study, we have identified several clades that are strongly supported by three gene regions, as well as clades that are less robust and likely to change with the addition of more characters.
Our data imply that the family Hesperiidae (1), as currently circumscribed, is monophyletic with strong support (BS 13), in agreement with the results of Wahlberg et al. (2005a). Six of seven currently recognized subfamilies of Hesperiidae are recovered as monophyletic clades (although not all represent subfamily-level taxa, see Figs 1 and 2), with the following relationships: (Coeliadinae + ("Pyrginae" including Pyrrhopyginae + (Heteropterinae + (Trapezitinae + Hesperiinae including Megathyminae)))). Monophyly of Coeliadinae (2) receives strong support (BS 12), and its basal position sister to the rest of the Hesperiidae corroborates the results of de Jong et al. (1996) and Wahlberg et al. (2005a). Although Pyrrhopyginae (45) is monophyletic, with strong support (BS 23), it is placed deep within one of the clades comprising "Pyrginae" (7), where its sister relationship to a clade (51) containing members of Evans' Tagiades group receives good support (44: BS 7). Pyrginae of previous authors is a paraphyletic grade of five major and two minor clades (Figs 1 and 2), including Pyrrhopyginae and Euschemon; these clades are discussed in detail below. Monophyly of Heteropterinae (89: minus Tsitana, see below) receives strong support (BS 14), and its position as sister to Trapezitinae (95) + Hesperiinae (108) receives good support (93: BS 9). Trapezitinae (95) is monophyletic with strong support (BS 19), and its position as sister to Hesperiinae corroborates the results of Wahlberg et al. (2005a, but Heteropterinae was not included). Monophyly of Hesperiinae (108) receives moderate support (BS 5). The two genera included in our analysis from Megathyminae (or "giant skippers") are sister taxa with strong support (129: BS 43), but this clade is placed deep within Hesperiinae, in a polytomy (110) with various Asian and African genera, also including the Neotropical genera Orses, Perichares (Carystus group) and Pyrrhopygopsis (Calpodes group). Additional taxa and characters will be needed to elucidate the phylogenetic position of the giant skippers.

In summary, our results imply that four subfamilies of Hesperiidae should be recognized: Coeliadinae, Heteropterinae, Trapezitinae and Hesperiinae. "Pyrginae" is a paraphyletic grade of seven clades, some of which should be recognized as tribal-level taxa. Further study is needed before a satisfactory classification of the "Pyrginae" will be possible, and additional characters and/or taxa are needed to elucidate the phylogenetic positions of Euschemon rafflesia and the giant skippers. 


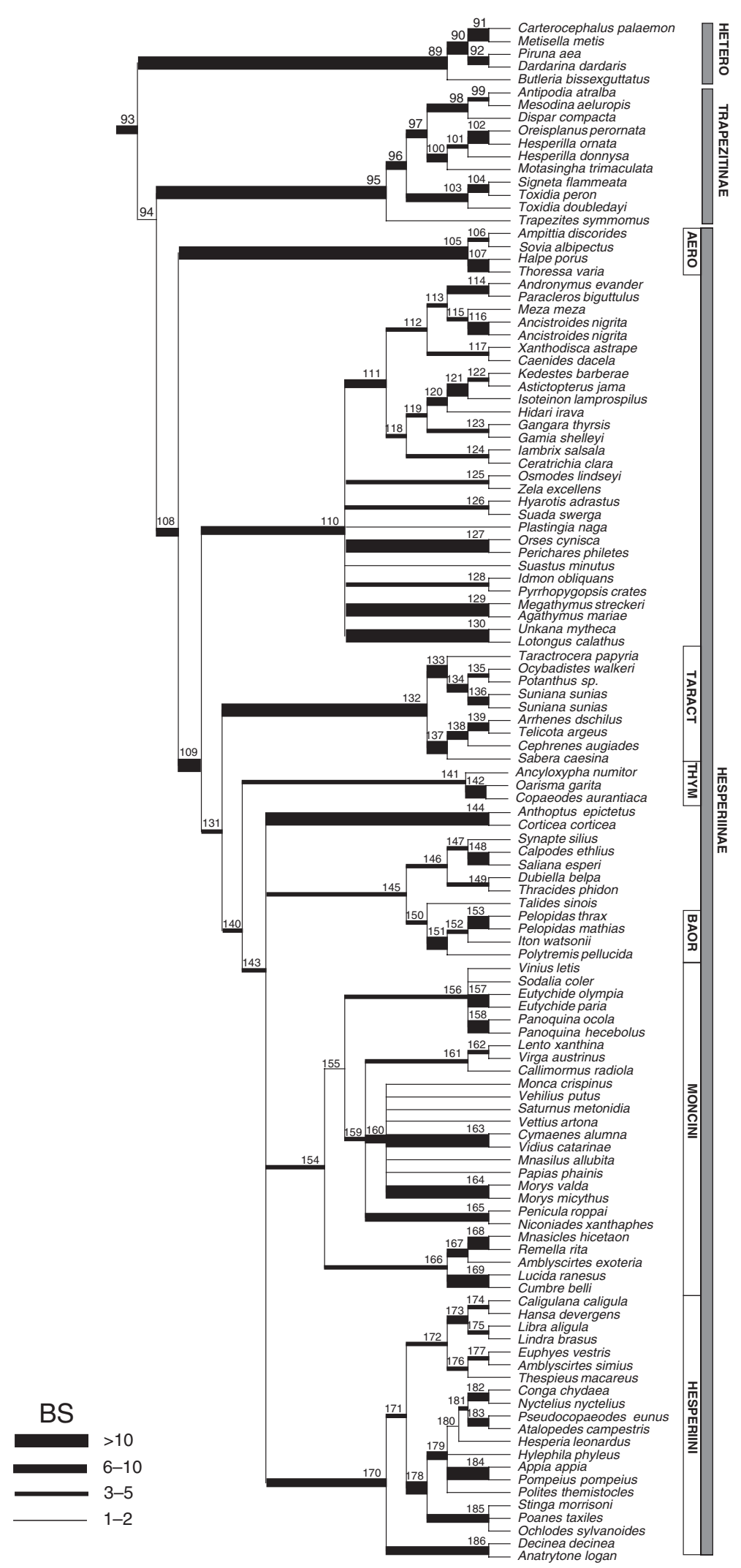

Fig. 2. Continuation of the cladogram shown in Fig. 1. HETERO $=$ Heteropterinae, AERO $=$ Aeromachini, BAOR $=$ Baorini, THYM $=$ Thymelicini, TARACT $=$ Taractrocerini. 
Table 3

Parameter estimates of the data for individual gene regions and the entire matrix

\begin{tabular}{lclcrrrrr}
\hline Gene region & \# Bases & Informative sites & Min. steps & \# Trees & Shortest tree & Intrinsic homoplasy & D homoplasy & Total support \\
\hline COI & 943 & 427 & 976 & 16442 & 9725 & $8749(90.0 \%)$ & 1004.3 \\
Ef-la & 740 & 259 & 566 & 11308 & 4581 & $4013(87.6 \%)$ & 1637.1 \\
Wingless $^{*}$ & 403 & 204 & 478 & $>60000$ & 4285 & $3807(88.8 \%)$ & 844.45 \\
Combined $^{2086}$ & 890 & 2020 & 90 & 19123 & $17103(89.4 \%)$ & $532(2.78 \%)$ & 1796.95 \\
\hline
\end{tabular}

*Eleven taxa missing wingless sequences were deleted from this analysis.

\section{Monophyly of Evans' generic groups and subgroups}

As shown in Table 5, only five of Evans' 28 generic groups within the various subfamilies of Hesperiidae were recovered as monophyletic clades, although we did not sample enough genera to assess the monophyly of the Isoteinon group or two groups of Pyrrhopyginae (Oxynetrini and the monotypic Zoniini). One of the monophyletic groups is Heteropterinae (89, equivalent to Evans' Carterocephalus group), which has since been widely regarded as a subfamily-level taxon (see Warren, 2006). Two of Evans' monophyletic genus-groups are in Pyrrhopyginae $(46,50)$, and were subsequently modified and elevated to tribal-level taxa by Mielke (2001). The other two monophyletic genus-groups are both within Hesperiinae: the Taractrocera group (132), which is strongly supported (BS 12; eight of 13 genera included), and the Gegenes group (151), which is also strongly supported (BS 30; three of 14 genera included) but is situated within a clade of hesperiines from several other groups (145, as discussed below). The remaining 23 generic groups defined by Evans are para- or polyphyletic, according to our results.

Only three of Evans' 38 generic subgroups were recovered as monophyletic clades (see Table 5), although we did not sample enough taxa to assess the monophyly of eight of these (excluding monotypic subgroups). The monophyletic groups are the Tagiades subgroup of the Tagiades group (54: BS 28; strongly supported but only two of ten genera included, which were once considered congeneric), the Paramimus subgroup of the Telemiades group (31: BS 55; very strongly supported, two of five genera included), and the Thymelicus subgroup of the Hesperia group (141: BS 4; moderate support, three of five genera included). The remaining subgroups are para- or polyphyletic. Based on these results, the use of Evans' generic groups and subgroups as a basis for a tribal classification cannot be considered satisfactory.

\section{Paraphyly of Pyrginae}

As noted above (Figs 1 and 2), our data suggest that Pyrginae of previous authors (e.g. Evans, 1937, 1949, $1952,1953)$ is a paraphyletic grade composed of several clades. This result is not surprising, as several recent workers have questioned the monophyly of the group. In the morphological analyses conducted by de Jong et al. (1996; see also Ackery et al., 1999), Pyrginae was "never" recovered as a monophyletic group, although their study included just ten skipper taxa. Larsen (2005) went as far as to say that "Pyrginae is certainly not monophyletic". In the combined molecular (three genes) and total evidence (molecular plus morphological) analyses conducted by Wahlberg et al. (2005a), only two species of pyrgines were included (Pyrgus and Urbanus), but these never formed a monophyletic group. Our data also failed to recover Pyrginae as a monophyletic group, although relationships implied (Fig. 1) among the clades of "Pyrginae" (8, 20, 33, 35, 42: all BS 1) receive weak support with strong incongruence among data partitions, and the arrangement of these clades is not likely to be robust to the addition of more characters. However, two $(9,36)$ of the five "major" clades in this group are strongly supported, and appear to represent tribal-level taxa, while components of the remaining major clades $(21,43,61)$ are also strongly supported and appear to represent tribal-level taxa, as discussed below. Until the clades of "Pyrginae" can be studied in more detail through the addition of more characters (e.g. morphology), and relationships between them can be better understood, we retain "Pyrginae" as an informal subfamily-level grouping composed of various tribes, but acknowledge its paraphyly by placing the name in quotation marks.

The sister taxon to other "Pyrginae" + Heteropterinae + Trapezetinae + Hesperiinae with weak support (8: BS 1) is the aptly named Clito aberrans. Throughout the course of this study, the position of $C$. aberrans has varied with the inclusion of additional taxa; various data sets have implied relationships with Quadrus + Pythonides, Milanion + Atarnes, and Eracon, among others. Evans (1953) placed Clito in his Antigonus subgroup of the Telemiades group, a placement retained by subsequent workers (e.g. Cock, 1998; Austin, 2000), none of whom has questioned its genus-group placement or commented on unusual morphological features. Based on this, we consider the current basal position of Clito in Fig. 1 to be spurious, and do not believe it represents its actual relationship to other members of "Pyrginae" (trees just two steps longer place Clito between Quadrus + Pythonides and Milanion + Atarnes). Of the six 
Table 4

Support indices for the branches in Figs 1 and 2. Partitioned branch support

\begin{tabular}{|c|c|c|c|c|c|}
\hline $\begin{array}{l}\text { Clade } \\
\text { number }\end{array}$ & COI & wg & Ef- $1 \alpha$ & $\begin{array}{l}\text { Branch } \\
\text { support }\end{array}$ & $\begin{array}{l}\text { Partition } \\
\text { congruence index }\end{array}$ \\
\hline 1 & -10.7 & 16.97 & 6.73 & 13 & 11.35 \\
\hline 2 & 3.47 & -12.12 & 20.65 & 12 & 9.98 \\
\hline 3 & -19.04 & 11.97 & 14.07 & 7 & 1.56 \\
\hline 4 & 4.47 & -10.03 & 14.56 & 9 & 6.77 \\
\hline 5 & 10.36 & -9.2 & 2.84 & 4 & -0.6 \\
\hline 6 & 14.32 & -15.55 & 10.23 & 9 & 5.54 \\
\hline 7 & 20.93 & -7.78 & -0.15 & 13 & 11.78 \\
\hline 8 & 0.24 & -8.76 & 9.52 & 1 & -16.52 \\
\hline 9 & 2.97 & 4.97 & 10.07 & 18 & 18 \\
\hline 10 & 0.3 & 3.8 & 1.9 & 6 & 6 \\
\hline 11 & 6.63 & -1.87 & 5.24 & 10 & 9.63 \\
\hline 12 & 1.3 & -5.37 & 14.07 & 10 & 8.93 \\
\hline 13 & 6.13 & -7.87 & 5.74 & 4 & 0.06 \\
\hline 14 & -3.82 & -0.65 & 17.46 & 13 & 12.3 \\
\hline 15 & 0.63 & -0.22 & 13.6 & 14 & 13.98 \\
\hline 16 & 0.24 & -8.76 & 9.52 & 1 & -16.52 \\
\hline 17 & 3.97 & 2.35 & 9.68 & 16 & 16 \\
\hline 18 & 30.81 & -15.19 & 1.38 & 17 & 15.21 \\
\hline 19 & 3.5 & -8.1 & 17.6 & 13 & 11.75 \\
\hline 20 & 0.24 & -8.76 & 9.52 & 1 & -16.52 \\
\hline 21 & 0.24 & -8.76 & 9.52 & 1 & -16.52 \\
\hline 22 & 0.47 & 1.13 & 5.4 & 7 & 7 \\
\hline 23 & 0.24 & -8.76 & 9.52 & 1 & -16.52 \\
\hline 24 & 6.13 & 2.63 & -4.76 & 4 & 1.62 \\
\hline 25 & 19.78 & -13.04 & -0.74 & 6 & 1.41 \\
\hline 26 & 0.75 & -9.77 & 16.02 & 7 & 4.21 \\
\hline 27 & 11.23 & 3.81 & 3.96 & 19 & 19 \\
\hline 28 & -17.14 & 12.51 & 14.63 & 10 & 6.57 \\
\hline 29 & 0.24 & -8.76 & 9.52 & 1 & -16.52 \\
\hline 30 & 0.24 & -8.76 & 9.52 & 1 & -16.52 \\
\hline 31 & 25.45 & 18.32 & 11.22 & 55 & 55 \\
\hline 32 & 10.42 & 11.31 & 2.27 & 24 & 24 \\
\hline 33 & 0.24 & -8.76 & 9.52 & 1 & -16.52 \\
\hline 34 & 14.72 & 2.3 & 3.98 & 21 & 21 \\
\hline 35 & 0.24 & -8.76 & 9.52 & 1 & -16.52 \\
\hline 36 & 3.56 & 13.87 & -3.42 & 14 & 13.52 \\
\hline 37 & 4.21 & 6.23 & -2.44 & 8 & 7.39 \\
\hline 38 & -2.64 & 14.6 & -2.96 & 9 & 7.76 \\
\hline 39 & 0.23 & 11.57 & 28.2 & 40 & 40 \\
\hline 40 & 5.61 & 1.09 & 18.3 & 25 & 25 \\
\hline 41 & 0.76 & -5.16 & 16.4 & 12 & 11.14 \\
\hline 42 & 0.24 & -8.76 & 9.52 & 1 & -16.52 \\
\hline 43 & -7.93 & 4.73 & 10.2 & 7 & 4.73 \\
\hline 44 & 30.88 & -21.87 & -2.01 & 7 & 0.18 \\
\hline 45 & 18.05 & -11.53 & 16.48 & 23 & 22 \\
\hline 46 & 12.13 & -1.17 & 13.03 & 24 & 23.89 \\
\hline 47 & 17.63 & -2.37 & -3.23 & 12 & 11.1 \\
\hline 48 & 4.52 & -7.48 & 11.96 & 9 & 7.34 \\
\hline 49 & 19.32 & -14.85 & 9.53 & 14 & 11.88 \\
\hline 50 & -5.37 & 13.3 & 26.07 & 34 & 33.68 \\
\hline 51 & 2.8 & -3.37 & 2.57 & 2 & -1.37 \\
\hline 52 & -7.87 & -5.37 & 24.23 & 11 & 8.58 \\
\hline 53 & 15.13 & -5.7 & -3.43 & 6 & 2.96 \\
\hline 54 & 11.8 & 6.66 & 9.54 & 28 & 28 \\
\hline 55 & 0.14 & 15.95 & -3.09 & 13 & 12.52 \\
\hline 56 & 11.3 & -5.2 & -3.1 & 3 & -2.53 \\
\hline 57 & 8.9 & 0.83 & -4.73 & 5 & 3.11 \\
\hline 58 & -8.83 & -1.27 & 19.1 & 9 & 6.76 \\
\hline 59 & -15.65 & 1.53 & 24.12 & 10 & 6.87 \\
\hline 60 & 0.24 & -8.76 & 9.52 & 1 & -16.52 \\
\hline
\end{tabular}

Table 4

Continued

\begin{tabular}{|c|c|c|c|c|c|}
\hline $\begin{array}{l}\text { Clade } \\
\text { number }\end{array}$ & COI & wg & Ef- $1 \alpha$ & $\begin{array}{l}\text { Branch } \\
\text { support }\end{array}$ & $\begin{array}{l}\text { Partition } \\
\text { congruence index }\end{array}$ \\
\hline 61 & 21.59 & -14.95 & -1.64 & 5 & -1.64 \\
\hline 62 & 0.24 & -8.76 & 9.52 & 1 & -16.52 \\
\hline 63 & 6.31 & -6.15 & 17.84 & 18 & 17.32 \\
\hline 64 & 0.24 & -8.76 & 9.52 & 1 & -16.52 \\
\hline 65 & 0.24 & -8.76 & 9.52 & 1 & -16.52 \\
\hline 66 & 9.8 & -9.03 & 0.23 & 1 & -17.06 \\
\hline 67 & 0.24 & -8.76 & 9.52 & 1 & -16.52 \\
\hline 68 & 0.24 & -8.76 & 9.52 & 1 & -16.52 \\
\hline 69 & 1.99 & 5.26 & 13.75 & 21 & 21 \\
\hline 70 & 0.24 & -8.76 & 9.52 & 1 & -16.52 \\
\hline 71 & 0.24 & -8.76 & 9.52 & 1 & -16.52 \\
\hline 72 & 0.24 & -8.76 & 9.52 & 1 & -16.52 \\
\hline 73 & -7.56 & 1.49 & 13.07 & 7 & 4.84 \\
\hline 74 & 25.21 & -14.79 & -5.42 & 5 & -3.08 \\
\hline 75 & 18.06 & -12.89 & -0.17 & 5 & -0.22 \\
\hline 76 & 0.24 & -8.76 & 9.52 & 1 & -16.52 \\
\hline 77 & 60.25 & -30.35 & -2.91 & 27 & 24.53 \\
\hline 78 & 0.24 & -8.76 & 9.52 & 1 & -16.52 \\
\hline 79 & 0.24 & -8.76 & 9.52 & 1 & -16.52 \\
\hline 80 & 0.24 & -8.76 & 9.52 & 1 & -16.52 \\
\hline 81 & 26.79 & -14.86 & -4.93 & 7 & 1.53 \\
\hline 82 & 0.24 & -8.76 & 9.52 & 1 & -16.52 \\
\hline 83 & 0.24 & -8.76 & 9.52 & 1 & -16.52 \\
\hline 84 & 1.4 & -9.43 & 9.03 & 1 & -17.86 \\
\hline 85 & 7.86 & -6 & 6.14 & 8 & 6.5 \\
\hline 86 & 21.74 & -12.41 & -1.33 & 8 & 4.57 \\
\hline 87 & 14.58 & -11.12 & -0.46 & 3 & -4.72 \\
\hline 88 & 29.04 & -18.44 & -3.6 & 7 & 0.7 \\
\hline 89 & -10.19 & 10.23 & 13.96 & 14 & 12.54 \\
\hline 90 & -5.53 & 7.13 & 11.4 & 13 & 12.15 \\
\hline 91 & 4.63 & 3.43 & 5.93 & 14 & 14 \\
\hline 92 & 12.8 & -4.03 & -0.77 & 8 & 6.8 \\
\hline 93 & -7.51 & 6.84 & 9.67 & 9 & 7.33 \\
\hline 94 & 19.58 & -11.95 & -5.63 & 2 & -15.58 \\
\hline 95 & 5.87 & 0.2 & 12.93 & 19 & 19 \\
\hline 96 & 1.53 & -13.35 & 19.82 & 8 & 4.66 \\
\hline 97 & -3.7 & 1.35 & 9.35 & 7 & 5.94 \\
\hline 98 & 15.4 & -7.93 & 0.53 & 8 & 6.02 \\
\hline 99 & 1.17 & -0.9 & 2.73 & 3 & 2.4 \\
\hline 100 & -25.01 & 9.1 & 24.91 & 9 & 3.44 \\
\hline 101 & 10.49 & -7.52 & 2.03 & 5 & 1.99 \\
\hline 102 & -2.2 & -0.8 & 22 & 19 & 18.68 \\
\hline 103 & -11.87 & -3.37 & 24.24 & 9 & 5.61 \\
\hline 104 & 0.8 & -6.87 & 12.07 & 6 & 3.71 \\
\hline 105 & 10.74 & 8.49 & -7.23 & 12 & 10.8 \\
\hline 106 & 3.97 & 0.63 & -1.6 & 3 & 1.93 \\
\hline 107 & 23.25 & 2.5 & -0.74 & 25 & 24.95 \\
\hline 108 & 8.3 & -3.03 & -0.27 & 5 & 3.68 \\
\hline 109 & -9.94 & -3.92 & 27.86 & 14 & 12.02 \\
\hline 110 & 14.16 & -14.86 & 6.7 & 6 & 1.05 \\
\hline 111 & 1.44 & -7.92 & 13.48 & 7 & 4.74 \\
\hline 112 & 18.05 & -15.37 & 1.32 & 4 & -3.69 \\
\hline 113 & -9.62 & -7.43 & 22.05 & 5 & -1.82 \\
\hline 114 & -0.03 & -14.37 & 23.4 & 9 & 5.80 \\
\hline 115 & -3.67 & -2.79 & 11.46 & 5 & 2.42 \\
\hline 116 & 50.15 & -3.42 & 34.28 & 81 & 80.93 \\
\hline 117 & 7.47 & -7.03 & 3.56 & 4 & 0.48 \\
\hline 118 & 14.28 & -15.57 & 5.29 & 4 & -3.79 \\
\hline 119 & -3.79 & -8.68 & 16.47 & 4 & -2.24 \\
\hline 120 & -5.37 & 2.63 & 10.74 & 8 & 6.66 \\
\hline 121 & 6.55 & -1.1 & 9.55 & 15 & 14.85 \\
\hline
\end{tabular}


Table 4

Continued

\begin{tabular}{|c|c|c|c|c|c|}
\hline $\begin{array}{l}\text { Clade } \\
\text { number }\end{array}$ & $\mathrm{COI}$ & wg & $\mathrm{Ef}-1 \alpha$ & $\begin{array}{l}\text { Branch } \\
\text { support }\end{array}$ & $\begin{array}{l}\text { Partition } \\
\text { congruence index }\end{array}$ \\
\hline 122 & -11.75 & -1.6 & 17.35 & 4 & -2.68 \\
\hline 123 & 7.57 & -12.01 & 9.44 & 5 & 0.2 \\
\hline 124 & -11.89 & -1.72 & 17.62 & 4 & -2.81 \\
\hline 125 & -2.45 & -4.87 & 11.32 & 4 & 0.34 \\
\hline 126 & 2.15 & -6.45 & 8.3 & 4 & 0.78 \\
\hline 127 & 10.8 & 3.78 & 12.43 & 27 & 27 \\
\hline 128 & 12.76 & -11.2 & 2.44 & 4 & -1.6 \\
\hline 129 & 9.13 & -3.58 & 37.42 & 43 & 42.8 \\
\hline 130 & 1.62 & -4.71 & 15.09 & 12 & 11.22 \\
\hline 131 & 4.24 & 0.13 & -1.37 & 3 & 2.09 \\
\hline 132 & 15.25 & -1.87 & -2.38 & 11 & 10.23 \\
\hline 133 & -0.21 & 9.68 & 8.53 & 18 & 17.98 \\
\hline 134 & -5.78 & -2.4 & 15.18 & 7 & 4.66 \\
\hline 135 & 2.24 & -10.24 & 13 & 5 & 0.9 \\
\hline 136 & -1.57 & -8.44 & 17.01 & 7 & 4.14 \\
\hline 137 & 16.76 & -14.99 & 10.23 & 12 & 9.5 \\
\hline 138 & -0.93 & -6.07 & 14 & 7 & 5 \\
\hline 139 & 1.83 & -1.6 & 5.77 & 6 & 5.47 \\
\hline 140 & 2.97 & 2.17 & -2.14 & 3 & 1.57 \\
\hline 141 & -2.18 & 2.21 & 3.97 & 4 & 2.91 \\
\hline 142 & -5.53 & 9.37 & 10.16 & 14 & 13.21 \\
\hline 143 & -3.6 & -2.43 & 11.03 & 5 & 2.59 \\
\hline 144 & 16.99 & -11.40 & 12.41 & 18 & 16.73 \\
\hline 145 & -6.57 & -6.9 & 16.47 & 3 & -5.98 \\
\hline 146 & 1.07 & -10.43 & 14.36 & 5 & 0.83 \\
\hline 147 & 1.39 & -13.28 & 16.89 & 5 & -0.31 \\
\hline 148 & 7.55 & 1.26 & 5.19 & 14 & 14 \\
\hline 149 & -2.57 & -3.9 & 11.47 & 5 & 2.41 \\
\hline 150 & 2.6 & -11.3 & 13.7 & 5 & 0.48 \\
\hline 151 & 10.95 & -7.24 & 20.3 & 24 & 23.41 \\
\hline 152 & 15.8 & -15.7 & 3.9 & 4 & -3.85 \\
\hline 153 & -6.2 & 9.8 & 13.4 & 17 & 16.27 \\
\hline 154 & -0.16 & -3.7 & 8.86 & 5 & 3.46 \\
\hline 155 & 2.94 & 3.65 & -4.59 & 2 & -2.59 \\
\hline 156 & 0.8 & -0.87 & 4.07 & 4 & 3.57 \\
\hline 157 & 14.99 & 0.13 & 9.88 & 25 & 25 \\
\hline 158 & 29.63 & -8.2 & 13.57 & 35 & 34.53 \\
\hline 159 & 2.73 & -8.27 & 10.54 & 5 & 1.69 \\
\hline 160 & 10.15 & -8.68 & 8.53 & 10 & 8.26 \\
\hline 161 & 13.13 & -12.37 & 4.24 & 5 & 0.05 \\
\hline 162 & 27.7 & -13.61 & -5.09 & 9 & 4.84 \\
\hline 163 & 16.68 & 5.44 & -1.12 & 21 & 20.89 \\
\hline 164 & 15.43 & -9.47 & 10.04 & 16 & 14.82 \\
\hline 165 & -6.38 & 5.06 & 7.32 & 6 & 3.87 \\
\hline 166 & 3.65 & -9.6 & 10.95 & 5 & 1.16 \\
\hline 167 & -10.27 & -2.12 & 20.39 & 8 & 4.9 \\
\hline 168 & -5.39 & -4.81 & 21.2 & 11 & 9.15 \\
\hline 169 & 7.73 & -11.27 & 18.53 & 15 & 13.49 \\
\hline 170 & -3.12 & -5.14 & 16.26 & 8 & 5.94 \\
\hline 171 & 2.16 & -6.82 & 9.66 & 5 & 2.27 \\
\hline 172 & -0.86 & -5.71 & 10.57 & 4 & 0.72 \\
\hline 173 & 6.73 & -11.1 & 12.37 & 8 & 5.23 \\
\hline 174 & 15.97 & 4.55 & -16.52 & 4 & -4.26 \\
\hline 175 & 22.95 & -17.72 & -1.23 & 4 & -5.48 \\
\hline 176 & 6.15 & -7.77 & 6.62 & 5 & 1.89 \\
\hline 177 & -11.6 & -2.93 & 19.53 & 5 & -0.81 \\
\hline 178 & 15.9 & -17.1 & 12.2 & 11 & 7.89 \\
\hline 179 & 20.89 & -8.34 & -6.55 & 6 & 1.04 \\
\hline 180 & -1.67 & 2.67 & 0 & 1 & -2.34 \\
\hline 181 & 25.97 & -16.2 & -4.77 & 5 & -3.39 \\
\hline 182 & 33.63 & -15.2 & -8.43 & 10 & 5.27 \\
\hline
\end{tabular}

Table 4

Continued

\begin{tabular}{lccrcc}
\hline $\begin{array}{l}\text { Clade } \\
\text { number }\end{array}$ & COI & wg & Ef-1 $\alpha$ & $\begin{array}{l}\text { Branch } \\
\text { support }\end{array}$ & $\begin{array}{l}\text { Partition } \\
\text { congruence index }\end{array}$ \\
\hline 183 & 24.9 & -18.01 & 1.11 & 8 & 3.5 \\
184 & 7.47 & 10.3 & -0.77 & 17 & 16.91 \\
185 & -1.23 & -5.39 & 14.62 & 8 & 6.35 \\
186 & 0.3 & -3.37 & 13.07 & 10 & 9.33 \\
\hline
\end{tabular}

remaining clades of the paraphyletic "Pyrginae", two of them are strongly supported (9: BS 18; 36: BS 14; corresponding to Erynnini and Carcharodini, see below), as is the small clade including just Quadrus and Pythonides (34: BS 21). Strongly supported components of the remaining three clades of "Pyrginae" include clade 45 (BS 24), corresponding to the Pyrrhopyginae of previous authors, and clade 55 (BS 13), which mostly includes members from Evans (1937, 1949) Celaenorrhinus group.

This is the first study to challenge the subfamily-level status of Pyrrhopyginae (Mielke, 2005; but see Wahlberg et al., 2005a); however its phylogenetic position deeply nested within "Pyrginae" (clade 45) has been robust to the addition of taxa and characters over the course of this study (e.g. Warren, 2004). When "Pyrginae" has appeared as a paraphyletic grade, as in the current study, Pyrrhopyginae never formed one of its "major" subdivisions. Given the topology of our cladogram, maintenance of the Pyrrhopyginae as a subfamily-level taxon would require recognition of at least seven additional subfamilies (clades 9, 22, 29, 36, 51, 55, 61) within what is currently circumscribed as "Pyrginae". In discussing the secondary sexual characters that partly serve to delineate groups within Pyrginae, Ackery et al. (1999) noted, "At first sight there is no apparent reason why the Pyrrhopyginae could not be a subordinate taxon of Pyrginae". Our results support that hypothesis.

In trees just two steps longer than the most parsimonious tree set, Pyrginae is recovered as a weakly supported monophyletic group, composed of two major clades. One of these clades includes members of clades 9 , 21, 34, 36 and 43 (Fig. 1), while the other major clade includes the same taxa as clade 61 (BS 5), including members of Evans' Augiades and Urbanus groups, also including a few species from the Celaenorrhinus and Telemiades groups (see below), as well as Euschemon rafflesia. The position of E. rafflesia at the base of this clade (62) is weakly supported (BS 1, with strong incongruence among partitions), and in trees just a few steps longer, E. rafflesia falls out of this clade into an unresolved polytomy including the rest of the Pyrginae. Thus, it would not be surprising if the phylogenetic position of E. rafflesia changes with the addition of 
Table 5

Monophyly of Evans' subfamilies and generic groups (as modified by Ackery et al., 1999 and Mielke, 2001), based on taxa sampled for this study.

\begin{tabular}{|c|c|}
\hline Group or subgroup & Monophyletic? \\
\hline Hesperiidae & Yes \\
\hline Coeliadinae & Yes \\
\hline Pyrrhopyginae & Yes (but within "Pyrginae") \\
\hline Pyrrhopygini & Yes \\
\hline Zoniini & Monotypic \\
\hline Passovini & Yes \\
\hline Oxynetrini & $?$ \\
\hline Pyrginae & No \\
\hline Augiades group & No \\
\hline Urbanus group & No \\
\hline Celaenorrhinus group & No \\
\hline "Old World" subgroup & No \\
\hline Bungalotis subgroup & No \\
\hline Nascus subgroup & Monotypic \\
\hline Porphyrogenes subgroup & ? \\
\hline Celaenorrhinus subgroup & No \\
\hline Tagiades group & No \\
\hline Netrocoryne subgroup & No \\
\hline Tagiades subgroup & Yes \\
\hline Caprona subgroup & $?$ \\
\hline Telemiades group & No \\
\hline Telemiades subgroup & No \\
\hline Nisoniades subgroup & No \\
\hline Staphylus subgroup & No \\
\hline Quadrus subgroup & No \\
\hline Pythonides subgroup & No \\
\hline Paramimus subgroup & Yes \\
\hline Antigonus subgroup & No \\
\hline Erynnis group & No \\
\hline Pyrgus group & No \\
\hline Heteropterinae & Yes (Tsitana excluded) \\
\hline Trapezitinae & Yes \\
\hline Hesperiinae & Yes (including Megathyminae) \\
\hline Astictopterus group & No \\
\hline Astictopterus Subgroup & $?$ \\
\hline Ampittia Subgroup & No \\
\hline Halpe Subgroup & No \\
\hline Isoteinon group & $?$ \\
\hline Ceratrichia group & No \\
\hline Acleros group & No \\
\hline Ploetzia group & No \\
\hline Ancistroides group & No \\
\hline Plastingia group & No \\
\hline Plastingia subgroup & No \\
\hline Erionota subgroup & No \\
\hline Unkana subgroup & No \\
\hline Prada subgroup & $?$ \\
\hline Vinius group & No \\
\hline Apaustus group & No \\
\hline Apaustus subgroup & No \\
\hline Phanes subgroup & $?$ \\
\hline Cymaenes subgroup & No \\
\hline Lerema subgroup & No \\
\hline Vettius subgroup & $?$ \\
\hline Carystus group & No \\
\hline Phlebodes group & No \\
\hline Phlebodes subgroup & No \\
\hline Oeonus subgroup & No \\
\hline Hesperia group & No \\
\hline Thymelicus subgroup & Yes \\
\hline
\end{tabular}

Table 5

Continued.

\begin{tabular}{ll}
\hline Group or subgroup & Monophyletic? \\
\hline Hesperia subgroup & No \\
Phemiades subgroup & No \\
Lerodea group & No \\
Calpodes group & No \\
Calpodes subgroup & No \\
Niconiades subgroup & No \\
Aides subgroup & $?$ \\
Thracides subgroup & No \\
Chloeria subgroup & Monotypic \\
Pseudosarbia subgroup & $?$ \\
Taractrocera group & Yes \\
Gegenes group & Yes \\
Megathyminae & Yes (but within Hesperiinae) \\
\hline
\end{tabular}

further data. However, our results highlight the affinity of Euschemon with other Hesperiidae, and suggest that the species belongs in this family, despite its morphological peculiarities.

\section{Circumscription of tribes}

No tribal-level classification has been proposed for Coeliadinae (2) or Heteropterinae (89), both of which are 'small' subfamilies with fewer than 15 genera. Morphology of the coeliadine genera is rather uniform (Ackery et al., 1999), and it seems unlikely the subfamily will be further subdivided in the future. Morphology of Heteropterinae is also rather uniform (Ackery et al., 1999), although its circumscription remains incomplete. Evans (1937) placed the genera Tsitana and Lepella in his African Astictopterus group (part of his Hesperiinae), together with Metisella and Hovala. Bridges (1993) retained all of these genera in the Astictopterus group, but Larsen (2005) included them all in Heteropterinae. When Tsitana is included in our combined analysis (data not shown), it groups with members of Evans' African Astictopterus and Ampittia groups (such as Astictopterus, Isoteinon and Kedestes, clade 121), well within Hesperiinae. We were unable to sample Hovala, but Evans (1937) believed it to be closely related to Metisella, and in our tree Metisella is sister to Carterocephalus (a genus undoubtedly related to Heteropterus), with strong support (91: BS 14). We were also unable to sample Lepella, and some other putative heteropterine genera, as indicated in Appendix 1. Therefore, we make no attempt to subdivide the Heteropterinae further, although further subdivision may be warranted with the addition of more taxa and characters.

Voss (1952) divided Trapezitinae (95) into two tribes, "Trapezitidi" (explicitly including just Trapezites) and "Hesperillidi". He divided the latter into two unnamed groups based on the presence or absence of a stigma on the male forewing, and on the number of metatibial 
spurs. One group (with a stigma and two pairs of spurs) explicitly included Dispar, Hesperilla, Signeta, and Toxidia, while the other group (without a stigma and with one pair of spurs) explicitly included only Mesodina. However, Waterhouse (1932) and various subsequent authors have recognized three major groupings within the Trapezitinae (e.g. Atkins, 1973; Common and Waterhouse, 1981; Ackery et al., 1999) that do not directly overlap with Voss' tribes, based on differences in larval foodplant families and characters of the larvae and pupae. These include (1) 'trapezitine' genera feeding primarily on Xanthorrhoeaceae and Poaceae (Trapezites, Anisynta, Pasma, Neohesperilla, Dispar, Toxidia, Signeta, and Croitana), (2) 'hesperilline' genera feeding only on Cyperaceae (Oreisplanus, Hesperilla, and Motasingha), and (3) the 'mesodine' genus feeding on Iridaceae (Mesodina). Larval foodplants of the New Guinean genera Hewitsoniella and Felicena remain unknown (Parsons, 1999), and foodplants of the genus Rachelia have recently been found to be in the Flagellariaceae (Braby, 2004). Recent research on relationships of trapezetine genera (e.g. Atkins, 1973, 1984, 1994) has not supported Waterhouse's groupings, and a separate informal grouping, the 'Proeidosa group,' has been proposed for Croitana and two recently described genera, Proeidosa and Antipodia (see Atkins, 1984, 1994). Despite the informal groupings identified by various authors, no formal tribal-level classification for the subfamily Trapezitinae has been employed since Voss' study (e.g. Bridges, 1993; Atkins and Edwards, 1996; Braby, 2000, 2004). Our results do not support the monophyly of Voss' tribes, but do support the monophyly of Waterhouse's three 'hesperilline' genera (100: BS 9). Our results also indicate that the 'trapezitine' genera are polyphyletic. When three other 'trapezitine' genera are added to our combined analysis (Anisynta, Neohesperilla and Pasma), for which data from only two genes is currently available, this arrangement does not change (data not shown). More genera are required to test the monophyly of the Proeidosa group, and its relationship to Mesodina. Until additional genera can be sampled and additional characters can be included (including those from immature stages), we feel it is premature to propose a tribal-level classification for the Trapezitinae.

The Megathyminae (or "giant skippers", clade 129) have previously been divided into three tribes (Stallings and Turner, 1958, 1959), an arrangement which has persisted among some authors (e.g. Mielke, 2004, 2005). However, many authors have treated the giant skippers as a family-level taxon within Hesperioidea (e.g. Comstock and Comstock, 1895; Barnes and McDunnough, 1912; Lindsey, 1921; Lindsey et al., 1931; McDunnough, 1938; Brown et al., 1956; dos Passos, 1964; Freeman, 1969b; Roever, 1975; Bridges, 1993). Our results indicate that the giant skippers are apparently a highly derived group of hesperiines (see Table 1), corroborating the views of Scott and Wright (1990) and Ackery et al. (1999). Furthermore, our results fail to support even tribal-level status for giant skippers, although such a status should not be ruled out until morphological characters are also considered.

As we have included only $35 \%$ of the world's genera of Hesperiidae in our combined analysis, inclusion of all skipper genera into a tribal classification must await a comprehensive morphological study to put our results into a broader context (A. Warren, J.R. Ogawa and A.V.Z. Brower, unpublished data). However, we have been able to identify certain clades with good or strong support, which are likely to be robust to the addition of taxa and characters, and appear to represent tribal-level entities. Recent efforts to construct a tribal nomenclature for Pyrginae and Hesperiinae have been regional in nature and are largely based on Evans' regional generic groups (Chou, 1994, 1998; Koçak and Seven, 1997). Based on our results (Figs 1 and 2), we propose a cosmopolitan tribal classification for "Pyrginae" and Hesperiinae, using available family-level names, to complement our revised subfamily-level arrangement (see Table 1). As the tribes of "Pyrginae" are arranged in a weakly supported paraphyletic grade (Fig. 1), the order in which they are discussed below does not imply any particular relationship among tribes, and mostly follows the order presented by Evans (1937, 1949, 1952, 1953).

\section{Tribes of "Pyrginae"}

Eudamini, confirmed status (61). This clade includes members of Evans' Augiades and Urbanus groups, as well as some members of his Celaenorrhinus and Telemiades groups (see Appendix 1). Recently, Mielke $(2004,2005)$ has arranged genera in Evans' Augiades and Urbanus groups, and American representatives of the Celaenorrhinus group, under the tribe Eudamini. Mielke's Eudamini (62: BS 1) was recovered as a weakly supported monophyletic group, with the addition of Spathilepia, Cogia and Telemiades (from the Telemiades group), and the removal of Celaenorrhinus. The Asian genus Lobocla (75, from the Celaenorrhinus group) is also included in Eudamini. As discussed above, Euschemon rafflesia is situated at the base of this clade, in a sister relationship with Mielke's Eudamini. For now we include Euschemon within Eudamini, although it is stressed that this placement should be considered tentative, until morphological characters can also be evaluated together with our molecular data. For the most part, relationships within the Eudamini are poorly supported by our data, although the monophyly of the clade including Urbanus (which itself is paraphyletic, see below), Thorybes, Achalarus, and Autochton receives good support (85: BS 8), and the sister relationships between Phocides + Nascus (63: BS 18), Polygonus + Telemiades (69: BS 21), and Typhedanus + Codatractus 
(77: BS 27) are strongly supported. Eudamini was originally proposed by Mabille (1877), and has been used at the tribal level by various authors (e.g. Mabille, 1878; Tutt, 1906 - in Tutt 1905-1914; Clark, 1948; Mielke and Casagrande, 1998; Lamas, 2003; Mielke, 2004, 2005).

Pyrrhopygini, reinstated status (45). Evans' (1951) generic groups for Pyrrhopyginae were modified and given tribal-level status by Mielke (2001). We were unable to sample representatives of two of these tribes, Oxynetrini and Zoniini (which is monotypic), but the monophyly of the two tribes we were able to sample, Pyrrhopygini (46: BS 24) and Passovini (50: BS 34), is strongly supported by our data. Inclusion of three additional genera for which we currently have only partial data (Yanguna, Jemadia and Mimoniades; data not shown) does not change the circumscription of Mielke's tribes. However, due to the position of Pyrrhopyginae within "Pyrginae" (Fig. 1), we treat the former subfamily as a tribe of "Pyrginae". This action changes the status of the tribes described by Mielke (2001), which can now be known as sub-tribes: Pyrrhopygina (46, new status), Zoniina (new status), Passovina (50, new status) and Oxynetrina (new status). Pyrrhopygini was originally proposed by Mabille (1877), and was emended to Pyrrhopyginae by Watson (1893), a spelling employed by all subsequent authors who recognized the group as a subfamily-level taxon (Mielke, 2005).

Tagiadini, confirmed status (51). Monophyly of Tagiadini receives weak support (BS 2) from our data, although the sister relationship (44: BS 7) between the New World Pyrrhopygini (45) and the Old World Tagiadini (51) receives good support. Relationships within Tagiadini receive good (53: BS 6) and strong support (52: BS 11; 54: BS 28). Not all members of Evans' Tagiades group are included within Tagiadini as defined by our cladogram (Fig. 1), which has the following topology: (Netrocoryne $+($ Darpa $+(E a-$ gris $+($ Daimio + Tagiades)))). We have incomplete data (two genes) for two additional genera, Gerosis and Odontoptilum, that when included in the combined analyses (data not shown) are also situated in this clade. Members of this tribe largely include those placed in the Tagiadini by Chou $(1994,1998)$, with the exception of Sarangesa and Pseudocoladenia (see below). Tagiadini was first proposed by Mabille (1878).

Celaenorrhinini, confirmed status (55). This clade (BS 13 ) is sister to Tagiadini + Pyrrhopygini, with good support (43: BS 7). According to our data, Evans' Celaenorrhinus group, given tribal status by Chou (1994, 1998), is polyphyletic. As noted above, Lobocla is in the Eudamini, and Euschemon is also tentatively placed there. In addition, all members sampled from
Evans' New World subgroups of the Celaenorrhinus group (including Bungalotis, Dyscophellus, Nascus, and $O c y b a$ ) are situated within Eudamini (63, 66, 71, 72). However, Celaenorrhinus species, along with a few additional genera, do form a monophyletic clade with strong support (BS 13), which appears to represent a tribal entity (Fig. 1). Genera in our study included within Celaenorrhinini are Celaenorrhinus, Pseudocoladenia, Sarangesa, Eretis, and Alenia. Eretis was formerly placed in Evans' Tagiades group, while Alenia was placed in Evans' Pyrgus group, based on similarities in wing pattern and antennal nudum number to the other 'checkered skippers', such as Pyrgus and Spialia. Relationships within Celaenorrhinini receive moderate (56: BS 3; 57: BS 5) and good (58: BS 9; 59: BS 10) support. The name "Celaenorrhinae" was first proposed by Swinhoe (1912), and was emended to Celaenorrhinini by Clark (1948), who treated the group as a tribe of the Pyrginae, in which he included species from Evans' Telemiades, Erynnis, and Pyrgus groups.

Carcharodini, reinstated status (36). This clade is strongly supported (BS 14) by our data, and is composed of members of Evans' Telemiades (Pachyneuria, Viola, Cyclosemia, Staphylus) and Pyrgus (Spialia, Carcharodus, Pholisora) groups, with the following topology: $\quad($ Cyclosemia $+($ Carcharodus + Spialia $)+$ $(($ Pachyneuria + Viola $)+($ Staphylus + Pholisora $)))$. Members of this clade occur widely in the Palaearctic (Carcharodus), African (Spialia), and Neotropical regions (remaining genera), extending to the Nearctic (Pholisora). Relationships within the Carcharodini receive good (37: BS 8; 38: BS 9) and strong support (40: BS 25; 41: BS 12), including the sister relationship between Staphylus and Pholisora (39: BS 40), corroborating Lindsey's (1921; also see Lindsey et al., 1931 and Stanford, 1981) belief that these genera are closely related (contra Evans, 1953). The name "Carcharodidi" was first proposed by Verity (1940), was used as a tribal name by Picard (1947), and was treated as a subtribe by Koçak (1989).

Achlyodidini, new status (29). The union of Achlyodes + Aethilla (both from Evans' Erynnis group) is strongly supported by our data (32: BS 24), although the clade uniting these genera with Milanion + Atarnes (30: BS 1) is weakly supported, as is the union of Eracon (from Evans' Telemiades group) with the other four genera (29: BS 1). Although Achlyodes and Aethilla are fairly similar skippers on morphological grounds (e.g. Warren, 1996), we see few characters that might suggest a close relationship between them, Atarnes + Milanion, and Eracon, and suggest that the clade (29) may not be robust to the addition of characters and taxa in future studies. However, the union of Atarnes + Milanion with Achlyodes + Aethilla has appeared in many anal- 
yses of these data over the course of this study, even though usually with weak support. In addition, Quadrus and Pythoniades, herein represented on their own clade within "Pyrginae" (Fig. 1), have often grouped with Atarnes + Milanion in previous analyses. We therefore suspect that the position of Quadrus + Pythoniades is likely to change in future analyses employing additional characters and/or taxa. The name "Achlyodidae" was proposed by Burmeister (1878) and has not since been used at the family level.

Erynnini, confirmed status (9). This clade is strongly supported (BS 18) by our data, and has been surprisingly robust to the addition of taxa and characters over the course of this study. Erynnini is composed of most members of Evans' Erynnis group, excluding Achlyodes and Aethilla (see above), and including some members of Evans' Telemiades group (Gorgythion, Sostrata, Mylon). Relationships within Erynnini mostly receive good (10: BS 6; 11: BS 10; 12: BS 10) and strong support (14: BS 13; 15: BS 14; 17: BS 16; 18: BS 17; 19: BS 13). Recently, Chou $(1994,1998)$ resurrected use of the name Erynnini at the tribal level for the sole Chinese representative of this clade, Erynnis. There is some question as to the correct authorship of the name Erynnini. At least four family-group names have been formed from the genus Erynnis (see Table 1), but only one of these, Erynnini Brues and Carpenter, 1932; is based on the genus as properly identified. As dictated by Code article 65.2.1 (ICZN, 1999), the case should be referred to the Commission for a ruling on each of these names. In the meantime, we treat these names as if the Commission has ruled to suppress all but the one properly proposed name (Table 1). Mielke (2005) credited Barnes and Lindsey (1922) with the authorship of "Erynninae". However, Barnes and Lindsey merely mentioned Erynninae as a possible replacement name for the subfamily Hesperiinae (known in recent decades as Pyrginae), and explicitly chose "Urbaninae" as their replacement name. Thus, it is unclear if Erynninae Barnes and Lindsey, 1922, can be considered to be validly proposed (ICZN, 1999 art. 12). If so, it has precedence over Brues and Carpenter's (1932) authorship.

Pyrgini, confirmed status (22). Whereas Chou (1994, 1998) applied the name Pyrgini to Chinese members of Evans' Pyrgus group, Mielke $(2004,2005)$ recently applied Pyrgini in a much broader way, to all New World genera of Pyrginae that were not included in Eudamini (sensu Mielke, 2004). As currently composed, with good support (22: BS 7), Pyrgini (Fig. 1) includes members of Evans' Pyrgus and Telemiades groups. Relationships within Pyrgini receive weak (23: BS 1), moderate (24: BS 4), good (25: BS 6; 26: BS 7; 28: BS 10), and strong support (27: BS 19). Xenophanes, for which we currently have only partial data (two genes), is also situated in this clade when it is included in our combined analyses (data not shown). One noteworthy aspect of our results is that the genera of 'checkered skippers' (Pyrgus, Spialia, Alenia), placed by Evans in his Pyrgus group, are undoubtedly polyphyletic, and are placed in three separate tribes (Pyrgini, Carcharodini and Celaenorrhinini, respectively).

\section{Tribes of Hesperiinae}

Aeromachini, new status (105). This clade is strongly supported (BS 12) by our data, and is sister to the rest of the Hesperiinae. Aeromachini includes some (but not all) members of Evans' Astictopterus group, including all three members of Evans' Halpe subgroup that were included in our analysis (Halpe, Thoressa, Sovia). The sister relationship between Halpe and Thoressa is strongly supported (107: BS 25), although our data provide only moderate support for the sister relationship between Ampittia and Sovia (106: BS 3). Although we were unable to sample the genus Aeromachus (the type genus of Aeromachini), its close relationship to Ampittia, Halpe, Thoressa, and Sovia is supported by the great similarity of male genital structures across these genera (as discussed and figured by Evans, 1937, 1949, and Inoué and Kawazoé, 1966), and we do not hesitate to associate Aeromachus at the tribal level with the four genera we studied. Aeromachini is apparently equivalent to the "Halpe group" proposed by Inoué and Kawazoé (1966), probably excluding Arnetta (see Eliot, 1978). Tutt (1906) originally proposed "Aeromachinae" as a subfamily and "Aeromachidi" as a tribe for Aeromachus, Ampittia, and Taractrocera, although Taractrocera belongs in a different tribe (see below).

Clade 110. This clade receives good support from our data (BS 6), but we consider its present composition to be tentative, as it contains a disparate mix of taxa that we feel are unlikely to be monophyletic, based on their morphology. In addition, the composition of this clade has varied widely over the course of this study (data not shown), and the large polytomy at clade 110 demonstrates the unresolved nature of relationships among taxa currently placed here. This clade mostly includes Old World genera from Evans' Astictopterus, Isoteinon, Ceratrichia, Acleros, Ploetzia, Ancistroides, and Plastingia groups, but also includes New World genera from Evans' Carystus and Calpodes groups, and Megathyminae (giant skippers). Despite the presence of a few strongly supported relationships (e.g. 121: BS 15), we feel that the composition of this clade is likely to change with the addition of more taxa and characters, and that its subdivision into more than one tribe in the future seems likely. However, the addition of Koruthaialos, Notocrypta, Pemara, Pyroneura, Gretna, and Pterotei- 
non in alternative analyses, for which we had only partial data (two genes), does not change the overall composition of this clade (data not shown).

As discussed above, the placement of giant skippers in this clade is not supported by any obvious morphological or biological evidence, but does suggest that they are 'highly derived' hesperiines that do not represent a family- or subfamily-level taxon. Although we are confident that the giant skippers are a derived hesperiine clade, we stress that additional study is required to determine their phylogenetic position within the Hesperiinae.

The tropical American genera Perichares and Orses were included in Evans' Carystus group. Their sister relationship is strongly supported (127: BS 27) by our data, but their relationship to other taxa in this clade is unresolved. Like the giant skippers, their placement in this clade has been robust to the addition of taxa over time, although their position within the clade has varied (data not shown). The placement of Pyrrhopygopsis (from Evans' Calpodes group) in this clade has been less stable (e.g. Warren, 2004).

Although the current composition of this clade is highly heterogenous, most of the Old World genera (at least) are likely to be closely related to each other, with respect to other tribes in the subfamily. Should clade 110 or groups therein prove to be robust to the addition of characters and taxa in future studies, several familygroup names are available for members of this clade (Table 1), and we have sampled type genera of many of these (Appenedix 2). However, none of these names has been widely used in the literature (see Mielke, 2005). Because of the heterogeneous nature of this grouping, we apply no family-group name to Clade 110 at this time, until its monophyly can be corroborated in future studies; the tentative placement of all associated familygroup names is incertae sedis (Table 1).

Taractrocerini, confirmed status (132). Voss (1952) was the first to treat this group as a tribal entity within Hesperiinae, but his concept of the group also included members of Thymelicini (from Evans' Thymelicus subgroup). Recently, Chou (1994, 1998) employed the tribe Taractrocerini for Chinese members of Evans' Taractrocera group. de Jong $(1990,2001,2003)$ studied relationships of 13 genera in this group, sensu Evans (1949, minus Prusiana), and noted that the group is apparently monophyletic. One of the few genus groups proposed by Evans that formed a monophyletic group in our study, the clade comprising Taractrocerini (132) is strongly supported by our data (BS 11), and is sister to the remaining tribes of the Hesperiinae, discussed below. Relationships between genera of Taractrocerini, as indicated by our data, do not entirely agree with those proposed by de Jong (2001, 2003), suggesting that more taxa need to be sampled in order to better resolve relationships in this tribe. For the most part, relationships among genera in this clade receive moderate or good support from our data, although two primary clades are strongly supported (133: BS 18; 137: BS 12).

Thymelicini, confirmed status (141). Tutt (1905, in Tutt 1905-1914) proposed the subfamily "Thymelicinae" and tribe "Thymelicidi" for members of the genus Thymelicus (an arrangement followed by Tutt, 1906; and 1906 in Tutt 1905-1914), but Evans (1949) included Thymelicus in his Hesperia group, an action followed by Voss (1952), who placed the genus in his tribe "Hesperiidi". Subsequently, Evans (1955) created the Thymelicus subgroup of his Hesperia group, in which he included Thymelicus, Adopaeoides, Ancyloxypha, Oarisma, and Copaeodes (see Appendix 1), the last three genera included by Voss in his tribe "Taractroceridi". Recently, Chou (1994, 1998) employed the name Thymelicini at the tribal level, in which he included just Thymelicus, the sole Chinese representative of this group. Although Thymelicus was not included in our study, as noted by Evans (1949, 1955), Thymelicus species share morphological features of the antennae, palpi, and male genitalia with the other four genera in his Thymelicus subgroup. de Jong (1984) and de Prins et al. (1992) figured the female genitalia of several Thymelicus species. Häuser (1993) commented on the peculiar structure of the corpus bursae in female Thymelicus, with a sclerotized ductus bursae interrupted by a membranous region where the ductus seminalis originates, and suggested this condition may represent a synapomorphy for the Thymelicus subgroup. Examination of the female genitalia of Ancyloxypha, Oarisma and Copaeodes (A.D.W. pers. obs.) has shown that the structure of the ductus bursae in these three species is similar to that found in Thymelicus, adding further evidence of a close relationship between them. Based on these morphological similarities, we apply the name Thymelicini to our clade (141) containing Ancyloxypha, Oarisma, and Copaeodes. However, monophyly of this clade receives only moderate support (BS 4) by our data, and the addition of Thymelicus and Adopaeoides in future studies is needed to test the stability of Thymelicini. Nevertheless, the sister relationship between Oarisma and Copaeodes, as implied by our data, is strongly supported (142: BS 14).

Baorini, new status (151). As noted above, our data strongly support the monophyly of Evans' Old World Gegenes group (151: BS 24), although only three genera from the group were included in our final analysis. We were unable to sample Baoris, but it shares many pupal and genitalic characters with Pelopidas, Polytremis, and Iton, as shown by Evans $(1937,1949)$ and especially by Bascombe et al. (1999), and we do not hesitate to associate Baoris with our three sampled genera, at the 
tribal level. The genus Caltoris, for which we currently have only partial data (two genes), is also situated in Baorini (151) when included in alternative analyses (data not shown). "Baorinae" was proposed by Doherty (1886), and was subsequently used at the subfamily level by Bell (1920, 1921, 1926), who included Baoris, Caltoris, Chapra (a junior subjective synonym of Pelopidas), Parnara, Gegenes, and Iton in the group (all of which were subsequently placed in Evans' 1949 Gegenes group, and in Chou's 1994, 1998 Gegenini).

However, our final analysis placed Talides, a New World genus from Evans' Carystus group, as sister to Baorini, with moderate support (150: BS 5). In addition, a moderately supported clade (146: BS 5) including members of Evans' Vinius (Synapte), Carystus (Dubiella) and Calpodes (Calpodes, Saliana, Thracides) groups is sister to the clade including Talides + Baorini, with moderate support (145: BS 3). While Dubiella, Calpodes, Saliana, and Thracides share various morphological characters (e.g. Evans, 1955), the inclusion of Synapte in this clade defies any obvious explanation, as it is a much smaller skipper and is morphologically more similar to some other genera in the Vinius group. These genera (excluding Synapte but possibly including Talides), along with related taxa (various genera from the Carystus and Calpodes groups), may eventually warrant tribal status, but for now we do not associate any family-group name with this clade (146). Should these genera occupy a tribal-level position in future studies, two names are potentially applicable, Carystini Mabille, 1878; and Calpodini Clark, 1948 (see Table 1).

Clade 144. A strongly supported clade (144: BS 18), including the New World genera Anthoptus and Corticea (from Evans' Vinius group), is part of a polytomy including Baorini and associated clades, and the following two tribes (Fig. 2). The position of this clade basal to the following two tribes, or in a polytomy with them, has been consistent over the course of this study, as characters and taxa have been added (data not shown). Although it is possible that this clade represents a triballevel entity, we feel that the addition of more characters or taxa is needed to corroborate our results, and for now do not associate any family-group name with this clade. We also note that no family-group name is currently available for this clade (Table 1).

Moncini A. Warren, new tribe (154). Type Genus: Monca Evans, 1955; - This clade receives moderate support (154: BS 5), and includes genera from Evans' Vinius (Lento, Vinius), Apaustus (Callimormus, Virga, Mnasicles, Sodalia, Lucida, Vidius, Monca, Cymaenes, Vehilius, Mnasilus, Remella, Papias, Morys, Cumbre, Vettius, Eutychide), Phlebodes (Saturnus, Penicula), Lerodea (Amblyscirtes exoteria - see below) and Calpodes (Panoquina, Niconiades) groups. Additional gen- era, for which we have incomplete data (two of three genes), are situated in this tribe in alternative analyses (data not shown), including Lerodea (from the Lerodea group), Parphorus (from the Apaustus group), Mucia (from the Phlebodes group), and Halotus (from the Calpodes group). We note that Halotus is sister to Niconiades, as predicted by Burns (1992a) based on morphological similarities. Although many relationships among genera in the Moncini receive good or strong support, the large polytomy at clade 160 probably reflects the need to sample additional taxa. We were surprised to find that, despite the abundance of familygroup names that have been proposed for Old World groups of Hesperiinae, no name is available to apply to clade 154.

Morphology of genera in this clade is rather diverse, and despite molecular characters that differentiate (ICZN 1999 Art. 13.1.1) Moncini from other tribes in our analysis, no putative morphological synapomorphies have yet been identified to diagnose the tribe. However, all genera we include in Moncini have forewing vein M2 originating much nearer to M3 than M1, and most species are "little brown skippers" (although some have yellow, tawny, or other colourful markings). Adults of some genera (e.g. Callimormus, Virga) have a long, slender, pointed third segment of the labial palpi (like that found in Thymelicini and some Taractrocerini). Secondary sexual characters of males include the variable presence of forewing stigmata, and in some genera (e.g. Vinius), a tuft of hair-like scales on the dorsal hindwing.

Hesperiini, confirmed status (170). Clark (1948) first recognized the tribe Hesperiini, in which he included various members of Evans' Apaustus, Hesperia, and Lerodea groups. Voss (1952) recognized the tribe "Hesperiidi", which included some members of Evans' Taractrocera, Hesperia, and Lerodea groups. Recently, Chou $(1994,1998)$ employed the name Hesperiini at the tribal level to represent Hesperia and Ochlodes, the sole Chinese genera in this group. In our study, this clade (170) is composed of members of Evans' Phlebodes, Hesperia, Lerodea, and Calpodes groups, and receives good support from our data (BS 8). Other than genera now placed in Thymelicini (141, see above), all genera in Evans' Hesperia group appear to be members of Hesperiini (except Halotus, see above). Some genera from Evans' Oeonus subgroup of the Phlebodes group are situated in this clade (Decinea, Caligulana, Conga), as are some members of Evans' Calpodes group (Thespieus, Nyctelius, Lindra) and one species from Evans' Lerodea group (Notamblyscirtes simius - see below). In addition, Xeniades (from Evans' Calpodes group), for which we currently have only partial data, is situated in this clade when included in our analyses, as sister to Thespieus (data not shown). For the most part, relationships between 
genera of Hesperiini receive moderate or good support by our data. Two clades receive strong support, including 178 (BS 11), and Appia + Pompeius (184: BS 17).

\section{Genus-level relationships}

More than one species from certain genera were included in our analysis. In both cases where two individuals of the same species were included, they emerged as sister taxa (116 Ancistroides nigrita, 136 Suniana sunias). However, in cases where two or more species from a genus were included, some congeners emerged as sister taxa (13 Ebrietas infanda + E. anacreon; 19 Erynnis afranius + E. horatius; 27 Pyrgus scriptura $+P$. ruralis; 153 Pelopidas mathias $+P$. thrax; 157 Euytchide olympia + E. paria; 158 Panoquina ocola + P. hecebolus; 164 Morys micythus + M. valda), while congeners discussed below did not.

We sampled two species of Urbanus (sensu Evans, 1952), $U$. dorantes and $U$. simplicius, members of Eudamini ("Pyrginae"). These did not emerge as sister taxa in our analysis, supporting Steinhauser's (1987) conclusion that the genus Urbanus is polyphyletic. Urbanus dorantes emerged in a sister relationship with Thorybes pylades (88: BS 7), and $U$. simplicius is sister to (Autochton $+($ Achalarus $+(U$. dorantes + T. pylades))), with good support (85: BS 8).

As noted by various authors (e.g. Lindsey and Miller, 1965; de Jong, 1982; de Jong and Treadaway, 1993; Austin and Steinhauser, 1996; Larsen, 2005), the pyrgine genus Celaenorrhinus is the only pan-tropical skipper genus. As discussed by de Jong (1982), this genus displays considerable morphological diversity, both in wing pattern and in the distribution of secondary sexual characters. We sampled one New World (C. eligius) and one Old World (C. leona) species of Celaenorrhinus, which did not appear as sister taxa in our analysis. Celaenorrhinus eligius emerged as sister to the remaining genera of Celaenorrhinini (55: BS 13), but C. leona is sister to Alenia, with moderate support (57: BS 5). Despite this, as we sampled just two of over 90 currently recognized species of Celaenorrhinus (Vane-Wright and de Jong, 2003), we feel it is premature to challenge the monophyly of the genus, as defined by de Jong (1982).

As currently circumscribed, the genus Pyrgus has an unusual Holarctic and Neotropical distribution (Warren, 1926; de Jong, 1972). We sampled three New World species of Pyrgus: P. ruralis, P. scriptura and P. communis. Two of these, $P$. ruralis and $P$. scriptura, emerged as sister taxa, with strong support (27: BS 18), while P. communis emerged as sister to Heliopetes, with good support (28: BS 7). This suggests that the genus Pyrgus may be paraphyletic with respect to Heliopetes and Heliopyrgus (see Austin and Warren, 2001). Until additional species of Pyrgus, Heliopyrgus, and Heliopetes can be sampled, we retain $P$. communis and its
New World relatives (e.g. P. c. chloe, P. albescens, $P$. adepta, $P$. orcynoides, $P$. oileus, $P$. orcus, $P$. brenda, P. philetas, $P$. veturius; see Austin and Warren, 2001) in the genus Pyrgus, but stress that this arrangement requires further study, and note that a new genus is perhaps needed at least for the primarily Neotropical $P$. communis group.

Within Trapezitinae, we sampled two species of Toxidia and two species of Hesperilla, but neither genus emerged as a monophyletic clade. Toxidia peron emerged as sister to Signeta flammeata (104: BS 6), and Toxidia doubledayi emerged as sister to T. peron + S. flammeata (103: BS 9). As noted by Atkins et al. (1991) based on the morphology of immatures and adults, Signeta is very closely related to Toxidia, and the two genera are separated primarily on the basis of differences in the size and shape of the male forewing stigma. Our results suggest that Toxidia may be paraphyletic with respect to Signeta, but we feel that the other species of Signeta (S. tymbophora), and additional species of Toxidia should be sampled and analysed before formally changing the composition or synonymy of these genera. The genus Hesperilla is morphologically diverse, with multiple species groups (Atkins, 1978). The two Hesperilla species we sampled are $H$. ornata and $H$. donnysa. Hesperilla ornata emerged as sister to Oreisplanus perornata, with strong support (102: BS 19), while $H$. donnysa is sister to $H$. ornata $+O$. perornata (101: BS 5). These results suggest that Hesperilla may be paraphyletic with respect to Oreisplanus, and that Oreisplanus might best be considered a 'species group' of Hesperilla. However, until the remaining species of Oreisplanus (O. munionga) and the 12 remaining species of Hesperilla can be sampled, we hesitate to disrupt the current generic arrangements (e.g. Atkins and Edwards, 1996; Braby, 2000, 2004).

Burns (1990) commented on the hesperiine genus Amblyscirtes, placed by Evans (1955) in his Lerodea group. He suggested that Amblyscirtes is not related to other members of the Lerodea group, and that it was closely related to genera in Evans' Apaustus group, such as Mnasicles and Remella. He also noted that one species, simius, did not belong in Amblyscirtes, based on male genitalia that "differ radically" from other species in the genus. However, over concern that simius may be related to a Neotropical genus unfamiliar to him, Burns treated simius as incertae sedis, and did not suggest to which of Evans' groups of hesperiine genera it may belong. Scott (2006) subsequently proposed the generic name Notamblyscirtes for simius. In addition to $N$. simius, we sampled one Amblyscirtes species, A. exoteria, whose presence in Amblyscirtes has not been disputed (e.g. Burns, 1990). According to our results, the two species are situated in separate tribes. Notamblyscirtes simius is in Hesperiini, in a sister relationship with Euphyes (177: BS 5). Amblyscirtes exoteria, presumably 
along with other Amblyscirtes species, is situated in Moncini, in a sister relationship with Mnasicles + Remella (167: BS 8), corroborating Burns' (1990) conclusion.

\section{Conclusion}

Here we have proposed a new family-level synonymy for the Hesperiidae, and have made a preliminary effort to establish a tribal nomenclature for the family (Table 1). We have identified several strongly supported monophyletic taxa, such as Pyrrhopygini, Erynnini, Trapezitinae, Aeromachini, and Taractrocerini, and have demonstrated strong support for the monophyly of the family. We have defined several unresolved issues that require further study, such as the paraphyly of "Pyrginae" and the phylogenetic position of "Megathyminae", a group we tentatively consider to be infra-tribal. We feel that the addition of more taxa and characters will be required to strengthen hypotheses of relationships presented here, but that our current arrangement represents a more natural classification than that proposed by Evans and modified by subsequent authors. We plan a second publication that will combine these data with morphological characters, and will use comparative morphology to integrate all genera of the Hesperiidae into a tribal classification (A. Warren, J.R. Ogawa and A.V.Z. Brower, unpublished data).

\section{Acknowledgements}

We offer sincere thanks to all those who provided specimens, without whom this study would not have been possible: Andrew Atkins, Jim Brock, Ernst Brockmann, Hide Chiba, Alexey Devyatkin, Scott Fitzgerald, Alan Heath, Yu-Feng Hsu, Daniel Janzen, Darlene Judd, Akito Kawahara, David Lohman, Kazuma Matsumoto, A. L. Monastyrskii, Debra Murray, Paul Opler, Tom Ortenburger, Michael Overton, Naomi Pierce, H. Tsukiyama, John Shuey, Jon D. Turner, Niklas Wahlberg, and Michael Whiting. We are grateful to our Brazilian colleagues for their ongoing support of our efforts. Thanks to Gi-Ho Sung for help operating the sequencing machine. Thanks also to former members of the JuddBrower laboratory (Oregon State University) for help and support with various aspects of this research: Jessica Adkins, Scott Fitzgerald, Miranda Jeansonne, Jason Leathers, Ming-Min Lee, Kelsey Miller, Debra Murray, Karina Silva-Brandão, Kim Tanner, Jill Townzen, and Alaine Whinnett. We also thank Andrew Atkins, Bernard Hermier, Rienk de Jong, Torben Larsen, Paul Opler, Jonathan Pelham and Niklas Wahlberg for comments on early versions of this manuscript, and George Austin, Michael Braby, Hideyuki Chiba, Alexey Devyatkin, Harold Greeney, Yu-Feng Hsu, Daniel Janzen, Darlene
Judd, David Lees, Christopher Marshall, Olaf Mielke, Paul Severns, Alvin Smith, and Joey Spatafora for discussions. This research was supported by the Harold and Leona Rice Endowment for Systematic Entomology, NSF DEB 0089886 and DEB 0640301 to A.V.Z.B., and NSF Doctoral Dissertation Improvement Grant DEB039005 to A.V.Z.B. and A.D.W. Additional funding was provided to A.D.W. by Howard and Edna Mae Warren, and by the McGuire Center for Lepidoptera and Biodiversity and DGAPA-UNAM during the final phase of this study.

\section{References}

Ackery, P.R., Smith, C.R., Vane-Wright, R.L., 1995. Carcasson's African Butterflies. An Annotated Catalogue of the Papilionidae and Hesperioidea of the Afrotropical Region. CSIRO, Melbourne.

Ackery, P.R., Jong, R. de, Vane-Wright, R.I., 1999. The butterflies: Hedyloidea, Hesperioidea and Papilionoidea. In: Kristensen, N.P. (Ed.), Lepidoptera, Moths and Butterflies. 1. Evolution, Systematics, and Biogeography. Handbook of Zoology. 4(35), Lepidoptera. de Gruyter, Berlin, pp. 263-300.

Atkins, A.F., 1973. A new genus Proeidosa for an Australian skipper, Pasma polysema (Lower) (Lepidoptera: Hesperiidae, Trapezitinae). J. Aust. Ent. Soc. 12, 253-260.

Atkins, A.F., 1978. The Hesperilla malindeva group from northern Australia, including a new species (Lepidoptera: Hesperiidae). J. Aust. Ent. Soc. 17, 205-215.

Atkins, A.F., 1984. A new genus Antipodia (Lepidoptera: Hesperiidae: Trapezitinae) with comments on its biology and relationships. Aust. Entomol. Mag. 11, 45-57.

Atkins, A.F., 1994. A new genus Herimosa (Lepidoptera: Hesperiidae: Trapezitinae) and its relationship to the Proeidosa group of endemic Australian skippers. Aust. Entomol. 21, 143-152.

Atkins, A.F., 2005. Skipper butterflies: their origins? A preliminary discussion on the higher systematics and a proposed phylogeny of the Hesperiidae. News Bull. Entomol. Soc. Queensland 33, 24-34.

Atkins, A.F., Edwards, E.D., 1996. Hesperioidea. In: Nielsen, E.S., Edwards, E.D., Rangsi, T.V. (Eds.), Checklist of the Lepidoptera of Australia. CSIRO Publishing, Victoria, pp. 232-236.

Atkins, A.F., Mayo, R., Moore, M., 1991. The life history of Signeta tymbophora (Meyrick and Lower) (Lepidoptera: Hesperiidae: Trapezitinae). Aust. Entomol. Mag. 18, 87-90.

Austin, G.T., 1997. Notes on Hesperiidae in northern Guatemala, with descriptions of new taxa. J. Lepidopterists' Soc. 51, 316-332.

Austin, G.T., 2000. Hesperiidae of Rondônia, Brazil: "Antigonus" genus group (Pyrginae), with taxonomic comments and descriptions of new species from Brazil and Guatemala. J. Lepidopterists' Soc. 54, 1-28.

Austin, G.T., DeVries, P.J., 2001. New Hesperiidae (Lepidoptera) from Costa Rica. Milwaukee Publ. Mus. Contrib. Biol. Geol. 96, 1-8.

Austin, G.T., Steinhauser, S.R., 1996. Hesperiidae of central Rondônia, Brazil: Celaenorrhinus Hübner (Lepidoptera: Pyrginae), with descriptions of three new species and taxonomic comments. Insecta Mundi 10, 25-44.

Austin, G.T., Warren, A.D., 2001. Taxonomic notes on some Neotropical skippers (Lepidoptera: Hesperiidae), Pyrgus, Heliopyrgus, and Heliopetes (Pyrginae). Dugesiana 8, 1-13.

Baker, R.H., DeSalle, R., 1997. Multiple sources of character information and the phylogeny of Hawaiian Drosophila. Syst. Biol. 46, 654-673.

Barnes, W., Lindsey, A.W., 1922. A review of some generic names in the order Lepidoptera. Ann. Entomol. Soc. Am. 15, 89-99. 
Barnes, W., McDunnough, J.H., 1912. Revision of the Megathymidae. Contrib. Nat. Hist. Lepid. North America 1, 1-45.

Bascombe, M.J., Johnston, G., Bascombe, F.S., 1999. The Butterflies of Hong Kong. Academic Press, London.

Bell, T.R., 1920-1927. The common butterflies of the plains of India (including those met with in the hill stations of the Bombay presidency). J. Bomb. Nat. Hist. Soc. 27, 26-32 (part 26, 1920), 211-227 (part 27, 1920), 431-447 (part 27, 1921), 778-793 (part 28, 1921); 28, 429-455 (part 29, 1923), 703-717 (part 30, 1923), 921-946 (part 31, 1923); 30, 132-150 (part 32, 1925), 285-305 (part 33, 1925), 561-586 (part 34, 1925), 822-837 (part 35, 1925); 31, 323-351 (part 36, 1926), 655-686 (part 37, 1926), 951-974 (part 38, 1927).

Braby, M.F., 2000. Butterflies of Australia: Their Identification, Biology and Distribution. CSIRO Publishing, Melbourne.

Braby, M.F., 2004. The Complete Field Guide to Butterflies of Australia. CSIRO Publishing, Collingwood, Australia.

Braby, M.F., Vila, R., Pierce, N.E., 2006. Molecular phylogeny and systematics of the Pieridae (Lepidoptera: Papilionoidea): higher classification and biogeography. Zool. J. Linn. Soc. 147, 238-275.

Bremer, K., 1988. The limits of amino acid sequence data in angiosperm phylogenetic reconstruction. Evolution 42, 795-803.

Bremer, K., 1994. Branch support and tree stability. Cladistics 10, 295304.

Bridges, C.A., 1993. Catalogue of the Family-Group, Genus-Group and Species-Group Names of the Hesperiidae (Lepidoptera) of the World. Published by Author, Urbana, IL.

Brower, A.V.Z., 1994. Phylogeny of Heliconius butterflies inferred from mitochondrial DNA sequences (Lepidoptera: Nymphalidae). Mol. Phylogenet. Evol. 3, 159-174.

Brower, A.V.Z., 2000. Phylogenetic relationships among the Nymphalidae (Lepidoptera) inferred from partial sequences of the wingless gene. Proc. R. Soc. Lond. B. Biol. Sci. 267, 1201-1211.

Brower, A.V.Z., 2006a. Problems with DNA barcodes for species delimitation: "ten species" of Astraptes fulgerator reassessed (Lepidoptera: Hesperiidae). System. Biodivers. 4, 1-6.

Brower, A.V.Z., 2006b. The how and why of branch support and partitioned branch support, with a new index to assess partition incongruence. Cladistics 22, 378-386.

Brower, A.V.Z., DeSalle, R., 1998. Patterns of mitochondrial versus nuclear DNA sequence divergence among nymphalid butterflies: the utility of wingless as a source of characters for phylogenetic study. Insect Mol. Biol. 7, 73-82.

Brower, A.V.Z., Jeansonne, M.M., 2004. Geographical populations and "subspecies" of New World monarch butterflies (Nymphalidae) share a recent origin and are not phylogenetically distinct. Ann. Entomol. Soc. Am. 97, 519-523.

Brower, A.V.Z., Freitas, A.V.L., Lee, M.-M., Silva-Brandão, K.L., Whinnett, A., Willmott, K.R., 2006. Phylogenetic relationships among the Ithomiini (Lepidoptera: Nymphalidae) inferred from one mitochondrial and two nuclear gene regions. Syst. Entomol. 14, 288-301.

Brown, F.M., Eff, J.D., Rotger, B., 1956. Colorado butterflies, Part 5: Hesperiidae and Megathymidae. Proc. Denver Mus. Nat. Hist. 7, 239-332.

Brues, C.T., Carpenter, F.M., 1932. Classification of insects. A key to the known families of insects and other terrestrial arthropods. Bull. Mus. Comp. Zool. Harvard College 73, 1-672.

Bucheli, S.R., Wenzel, J.W., 2005. Gelechioidea (Insecta: Lepidoptera) systematics: a reexamination using combined morphology and mitochondrial DNA. Mol. Phylogenet. Evol. 35, 380-394.

Burmeister, H.C.C., 1878 Description Physique de la République Argentine D'après des Observations Personelles et Étrangères. Tome 5. Lépidoptères (1); Diurnes, Crepusculaires et Bombycoides. Buenos Aires: Paul Emile Coni/Paris: F. Savy/Halle: E. Anton.

Burns, J.M., 1990. Amblyscirtes: problems with species, species groups, the limits of the genus, and genus groups beyond- a look at what is wrong with the skipper classification of Evans (Hesperiidae). J. Lepidopterists' Soc. 44, 11-27.

Burns, J.M., 1992a. Genitalic characterization, enlargement, and reassociation of the Neotropical hesperiine genus Halotus (Hesperiidae). J. Lepidopterists' Soc. 46, 182-194.

Burns, J.M., 1992b. Genitalic recasting of Poanes and Paratrytone (Hesperiidae). J. Lepidopterists' Soc. 46, 1-23.

Burns, J.M., 1994a. Genitalia at the generic level: Atrytone restricted, Anatrytone resurrected, new genus Quasimellana- and yes! we have no Mellanas (Hesperiidae). J. Lepidopterists' Soc. 48, 273-337.

Burns, J.M., 1994b. Split skippers: Mexican genus Poanopsis goes in the origenes group- and Yvretta forms the rhesus group- of Polites (Hesperiidae). J. Lepidopterists' Soc. 48, 24-45.

Burns, J.M., 1996. Genitalia and the proper genus: Codatractus gets mysie and uvydixa- in a compact cyda group- as well as a hysterectomy, while Cephise gets part of Polythrix (Hesperiidae: Pyrginae). J. Lepidopterists' Soc. 50, 173-216.

Burns, J.M., 1999. Pseudodrephalys: a new genus comprising three showy, Neotropical species (one new) removed from - and quite remote from - Drephalys (Hesperiidae: Pyrginae). J. Lepidopterists' Soc. 52, 364-380.

Burns, J.M., Janzen, D.H., 2005. What's in a name? Lepidoptera: Hesperiidae: Pyrginae: Telemiades Hübner 1819 [Pyrdalus Mabille 1903]: New combinations Telemiades corbulo (Stoll) and Telemiades oiclus (Mabille) - and more. Proc. Entomol. Soc. Washington 107, 770-781.

Butler, A.G., 1870. The genera of Hesperiidae in the collection of the British Museum. Entomol. Monthly Mag. 7, 55-58, 92-99.

Caterino, M.S., Reed, R.D., Kuo, M.M., Sperling, F.A.H., 2001. A partitioned likelihood analysis of swallowtail butterfly phylogeny (Lepidoptera: Papilionidae). Syst. Biol. 50, 106-127.

Chiba, H., 1995. A Revision of the Subfamily Coeliadinae of the World. PhD thesis, University of Hawaii.

Chiba, H., 1997. Miscellaneous notes on skippers. Konchu to Shizen [Nature and Insects] 32, 29-33. [In Japanese]

Chiba, H., Tsukiyama, H., 1994. A review of the genus Pirdana Distant (Lepidoptera: Hesperiidae). Butterflies 6, 19-26.

Chiba, H., Hirowatari, T., Ishii, M., Yagi, T., Tanigawa, Y., Hasebe, M., Mohri, H., 2001. Phylogeny of Japanese skippers inferred from the nucleotide sequences of the mitochondrial ND5 gene (Lepidoptera: Hesperiidae), provisional communication. Newsl. Soc. DNA Butterflies 7, 6-9. [In Japanese]

Cho, S., Mitchell, A., Regier, J.C., Mitter, C., Poole, R.W., Friedlander, T.P., Zhao, S., 1995. A highly conserved nuclear gene for low-level phylogenetics: elongation factor la recovers morphology-based tree for heliothine moths. Mol. Biol. Evol. 12, 650-656.

Chou, I. (Ed.), 1994. Monographia Rhopalocerorum Sinensium. Henan Scientific and Technological Publishing House, Henan, China.

Chou, I., 1998. Classification and Identification of Chinese Butterflies. Henan Scientific and Technological Publishing House, Henan, China.

Clark, A.H., 1948. Classification of the butterflies, with the allocation of the genera occurring in North America north of Mexico. Proc. Biol. Soc. Washington 61, 77-84.

Clary, D.O., Wolstenholme, D.R., 1985. The mitochondrial DNA molecule of Drosophila yakuba: nucleotide sequence, gene organization, and genetic code. J. Mol. Evol. 22, 252-271.

Cock, M.J.W., 1998. The skipper butterflies (Hesperiidae) of Trinidad. Part 9, Genera group E concluded (third section) with a description of a new species of Clito. Living World. J. Trinidad Tobago Field Naturalists' Club 1997-1998, 33-45.

Common, I.F.B., Waterhouse, D.F., 1981. Butterflies of Australia. Angus \& Robertson, Sydney.

Comstock, J.H., Comstock, A.B., 1895. A Manual for the Study of Insects. Comstock Publishing Company, Ithaca, NY. 
Devyatkin, A.L., 1996. New Hesperiidae from north Vietnam, with the description of a new genus (Lepidoptera: Rhopalocera). Atalanta 27, 595-604.

Devyatkin, A.L., 2002. Hesperiidae of Vietnam, 11. New taxa of the subfamily Hesperiinae (Lepidoptera, Hesperiidae). Atalanta 33, $127-135$.

Doherty, W., 1886. A list of butterflies taken in Kumaon. J. Asiatic Soc. Beng. 55, 103-140.

Eliot, J.N., 1978. [descriptions and revisions] In: Corbet, A.S., Pendlebury, H.M. The Butterflies of the Malay Peninsula, 3rd edn. Malayan Nature Society, Kuala Lumpur, Malaysia, v-xiv + 578pp.

Evans, W.H., 1937. A Catalogue of the African Hesperiidae. British Museum (Natural History), London.

Evans, W.H., 1949. A Catalogue of the Hesperiidae From Europe, Asia, and Australia in the British Museum (Natural History). British Museum, London.

Evans, W.H., 1951. A Catalogue of the American Hesperiidae Indicating the Classification and Nomenclature Adopted in the British Museum (Natural History). Part I. Pyrrhophyginae. British Museum, London.

Evans, W.H., 1952. A Catalogue of the American Hesperiidae Indicating the Classification and Nomenclature Adopted in the British Museum (Natural History). Part II. Pyrginae. Section I. British Museum, London.

Evans, W.H., 1953. A Catalogue of the American Hesperiidae Indicating the Classification and Nomenclature Adopted in the British Museum (Natural History). Part III. Pyrginae. Section II. British Museum, London.

Evans, W.H., 1955. A Catalogue of the American Hesperiidae Indicating the Classification and Nomenclature Adopted in the British Museum (Natural History). Part IV. Hesperiinae and Megathyminae. British Museum, London.

Fan, X., Wang, M., Zeng, L., 2007. The genus Idmon de Nicéville (Lepidoptera: Hesperiidae) from China, with description of two new species. Zootaxa 1510, 57-62.

Farris, J.S., Källersjö, M., Kluge, A.G., Bult, C., 1994. Testing the significance of incongruence. Cladistics 10, 315-320.

Freeman, H.A., 1969a. Records, new species, and a new genus of Hesperiidae from Mexico. J. Lepidopterists' Soc. 23 (Suppl. 2), 1-62.

Freeman, H.A., 1969b. Systematic review of the Megathymidae. J. Lepidopterists' Soc. 23 (Suppl. 1), 1-59.

Gatesy, J., O'Grady, P., Baker, R.H., 1999. Corroboration among data sets in simultaneous analysis: hidden support for phylogenetic relationships among higher level artiodactyl taxa. Cladistics 15, 271-313.

Goloboff, P.A., 1999. NONA, Version 2.0. Published by the author, New York, NY.

Häuser, C.L., 1993. Die inneren weiblichen Genitalorgane der Tagfalter (Rhopalocera), Vergleichende Morphologie und phylogenetische Interpretation (Insecta, Lepidoptera). Zoologische Jahrbücher. Abteilung für Systematik, Ökologie und Geographie der Tiere 120, 389-439.

Hebert, P.D.N., Penton, E.H., Burns, J.M., Janzen, D.H., Hallwachs, W., 2004. Ten species in one: DNA barcoding reveals cryptic species in the Neotropical skipper butterfly Astraptes fulgerator. Proc. Nat. Academy Sci. USA 101, 14812-14817.

Higgins, L.G., 1976. The Classification of European Butterflies. Collins, London.

Inoué, S., Kawazoé, A., 1966. Hesperiid butterflies from South Vietnam (3). Tyô to Ga 16, 84-99.

International Commission on Zoological Nomenclature (ICZN), 1999. International Code of Zoological Nomenclature, 4th edn. The International Trust for Zoological Nomenclature, London.

Janse, A.J.T., 1925. Key to the families, sub-families and tribes of the Lepidoptera, with special reference to the South African species. S. Afr. J. Sci. 22, 318-345. de Jong, R., 1972. Systematics and geographic history of the genus Pyrgus in the Palaearctic region (Lepidoptera: Hesperiidae). Tijdschr. Entomol. 115, 1-121.

de Jong, R., 1982. Secondary sexual characters in Celaenorrhinus and the delimitation of the genus (Lepidoptera, Hesperiidae). J. Nat. Hist. 16, 695-705.

de Jong, R., 1983. Annotated list of the Hesperiidae (Lepidoptera) of Surinam, with descriptions of new taxa. Tijdsch. Entomol. 126, 233-268.

de Jong, R., 1984. Notes on the genus Thymelicus Hübner (Lepidoptera, Hesperiidae). Nota Lepidopterol. 7, 148-163.

de Jong, R., 1990. Some aspects of the biogeography of the Hesperiidae (Lepidoptera, Rhopalocera) of Sulawesi. In: Knight, W.J., Holloway, J.D. (Eds.), Insects and the Rain Forests of South East Asia (Wallacea). Royal Entomological Society of London, pp. $35-42$.

de Jong, R., 2001. Faunal exchange between Asia and Australia in the Tertiary as evidenced by recent butterflies. In: Metcalfe, I., Smith, J.M.B., Morwood, M., Davidson, I. (Eds.), Faunal and Floral Migrations and Evolution in SE Asia-Australia. A. A. Balkema Publishers, Lisse, pp. 133-146.

de Jong, R., 2003. Are there butterflies with Gondwanan ancestry in the Australian region? Invertebr. Syst. 17, 143-156.

de Jong, R., Treadaway, C.G., 1993. The Hesperiidae (Lepidoptera) of the Philippines. Zool. Verhandel. 288, 1-125.

de Jong, R., Vane-Wright, R.I., Ackery, P.R., 1996. The higher classification of butterflies (Lepidoptera), problems and prospects. Entomol. Scand. 27, 65-101.

Koçak, A.Ö., 1989. On the butterflies of Yugoslavia (Lepidoptera). Priamus 5, 3-22, 1 map.

Koçak, A.Ö., Seven, S., 1997. Negros Papilionoidea, Hesperioidea faunasi ve taksonomisi úzerine ara tirmalar (Lepidoptera). Priamus 9, 57-116.

Lamas, G., 2003. Las Mariposas de Machu Picchu. Guía Ilustrada de las Mariposas del Santuario Histórico Machu Picchu, Cuzco, Perú. PROFONANPE, Lima, Peru.

Lamas, G. (Ed.), 2004. Checklist: Part 4A. Papilionoidea - Hesperioidea. In: Heppner, J.B. (Ed.), Atlas of Neotropical Lepidoptera. Scientific Publishers, Gainesville, Florida.

Larsen, T.B., 2005. Butterflies of West Africa, 2 Vols. Apollo Books, Stenstrup.

Lindsey, A.W., 1921. The Hesperioidea of America north of Mexico. Denison University Bulletin. Univ. Iowa Studies Nat. Hist. 9, 1114.

Lindsey, A.W., Miller, L.D., 1965. Hesperioidea. In: Fox, R.M., Lindsey, A.W., Clench, H.K., Miller, L.D. (Eds.), The Butterflies of Liberia. Mem. Am. Entomol. Soc. 19, 1-438.

Lindsey, A.W., Bell, E.L., Williams, R.C. Jr, 1931. The Hesperioidea of North America. Denison University Bulletin 26, 1-142.

Mabille, P., 1876. Sur la classification des Hespériens avec la description de plusieurs espèces nouvelles. Ann. Société Entomol. France 6 (2), 251-274.

Mabille, P., 1877. Descriptions de Lépidoptères nouveaux de groupe des Hespérides (8-13). Petit. Nouv. Entomol. 2, 161-162.

Mabille, P., 1878. Catalogue des Hespérides du Musée Royal d'Historie Naturelle de Bruxelles. Ann. Société Entomol. Belg. $21,12-44$.

Mabille, P., 1903-1904. Lepidoptera Rhopalocera. Family Hesperiidae. Genera Insec. 17a, 1-78 \{[21 Sep] 1903\}; 17b, 79-142\{[Apr] 1904\}; 17c, 143-182 \{[13 May] 1904); 17d, 183-210 \{[27 Aug] 1904\}.

Maruyama, K., 1991. Hesperiidae. Butterflies Borneo 2, i-xiii + 1-82 pp. [In Japanese]; i-ix $+1-77$ pp. [In English]. Published by the author, Tokyo.

Mayo, R., Atkins, A.F., 1992. Anisyntoides Waterhouse (Lepidoptera: Hesperiidae), a synonym of Trapezites Hübner, with description of a new species from western Australia. Aust. Entomol. Mag. 19, 8188. 
McDunnough, J.H., 1938. Check list of the Lepidoptera of Canada and the United States of America, Part 1, Macrolepidoptera. Mem. South. Calif. Acad. Sci. 1, 3-272.

Mickevich, M.F., Farris, J.S., 1981. The implications of congruence in Menidia. Syst. Zool. 30, 351-370.

Mielke, O.H.H., 1968. Lepidoptera of the central Brazil plateau. II. New genera, species, and subspecies of Hesperiidae. J. Lepidopterists' Soc. 22, 1-20.

Mielke, O.H.H., 1977. Paracogia acanthopoda gen. e sp. n. de Hesperiidae do Paraná, Brasil (Lepidoptera). Dusenia 10, 77-81.

Mielke, O.H.H., 1980. Contribuição ao estudo faunístico dos Hesperiidae americanos VI. Nota suplementar às espécies de Hesperiinae do Rio Grande do Sul, Brasil (Lepidoptera). Acta Biol. Par. $8 / 9,127-172$.

Mielke, O.H.H., 1992. Notas sinonímicas sobre Hesperiidae Neotropicais, com descrições de novos géneros, espécies e subspecies (Lepidoptera). Rev. Brasil. Zool. 7, 503-524.

Mielke, O.H.H., 1995. Revisão de Elbella Evans e gêneros afins (Lepidoptera, Hesperiidae, Pyrrhopyginae). Rev. Brasil. Zool. 11, 395-586.

Mielke, O.H.H., 2001. Estudo cladístico e descrições de tribos em Pyrrhopyginae (Lepidoptera, Hesperiidae). Rev. Brasil. Zool. 18, 897-905.

Mielke, O.H.H., 2002. Pyrrhopyginae: gêneros novos e revalidados (Lepidoptera, Hesperiidae). Rev. Brasil. Zool. 19, 217-228.

Mielke, O.H.H., 2004. Hesperiidae. In: Lamas, G. (Ed.), Checklist: Part 4A. Papilionoidea - Hesperioidea, In: Heppner, J.B. (Ed.), Atlas of Neotropical Lepidoptera. Scientific Publishers, Gainesville, Florida, pp. 25-86.

Mielke, O.H.H., 2005. Catalogue of the American Hesperioidea: Hesperiidae (Lepidoptera). Sociedade Brasileira de Zoologia, Curitiba, Paraná, Brazil. 6 vols.

Mielke, O.H.H., Casagrande, M.M., 1998. Papilionoidea e Hesperioidea (Lepidoptera) do Parque Estadual do Morro do Diablo, Teodoro Sampaio, São Paulo, Brasil. Rev. Brasil. Zool. 14, 9671001 .

Mielke, O.H.H., Casagrande, M.M., 2002. Notas taxonômicas em Hesperiidae neotropicais, com descrições de novos taxa (Lepidoptera). Rev. Brasil. Zool. 19 (Suppl. 1), 27-76.

Mielke, O.H.H., Casagrande, M.M., 2003. Saniba nom. nov. para Sabina Evans (Lepidoptera, Hesperiidae, Hesperiinae). Rev. Brasil. Zool. 20, 775.

Miller, L.D., 1965. A review of the West Indian "Choranthus". J. Res. Lepidoptera 4, 259-274.

Monteiro, A., Pierce, N.E., 2001. Phylogeny of Bicyclus (Lepidoptera: Nymphalidae) inferred from COI, COII, and EF-1alpha gene sequences. Mol. Phylogenet. Evol. 18, 264-281.

Nixon, K.C., 1999. The parsimony ratchet, a new method for rapid parsimony analysis. Cladistics 15, 407-414.

Opler, P.A., Warren, A.D., 2002. Butterflies of North America. 2. Scientific Names List for Butterfly Species of North America, North of Mexico. Contributions of the C. P. Gillette Museum of Arthropod Diversity, Colorado State University, Fort Collins, CO.

Parsons, M., 1999. The Butterflies of Papua New Guinea. Their Systematics and Biology. Academic Press, London.

dos Passos, C.F., 1964. A synonymic list of the Nearctic Rhopalocera. Lepidopterists' Soc. Mem. 1, 1-145.

Peña, C., Wahlberg, N., Weingartner, E., Kodandaramaiah, U., Nylin, S., Freitas, A.V.L., Brower, A.V.Z., 2006. Higher level phylogeny of Satyrinae butterflies (Lepidoptera: Nymphalidae) based on DNA sequence data. Mol. Phylogenet. Evol. 40, $29-49$.

Picard, J., 1947. Notes sur les Hesperiidae Pyrginae des regions palaéarctiques. Tribus Erynnidi, Carcharodidi, et Pyrgidi. Bull. Soc. Entomol. France 52, 129-134.

Prins, W.O., van der Poorten, D., de Jong, R., 1992. Rhopalocera and Grypocera of Turkey 10. Description of the female of Thymelicus novus (Reverdin, 1916) and additional notes on the female genitalia of some Thymelicus species (Lepdioptera: Hesperiidae). Phegea 20, $137-150$.

Pyle, R.M., 2002. The Butterflies of Cascadia. A Field Guide to all the Species of Washington, Oregon, and Surrounding Territories. Audobon Society, Seattle.

Regier, J.C., Mitter, C., Peigler, R.S., Freidlander, T.P., 2000. Phylogenetic relationships in Lasiocampidae (Lepidoptera), initial evidence from elongation factor-1alpha sequences. Insect Syst. Evol. 31, 179-186.

Regier, J.C., Mitter, C., Peigler, R.S., Friedlander, T.P., 2002. Monophyly, composition, and relationships within Saturniinae (Lepidoptera: Saturniidae), Evidence from two nuclear genes. Insect Syst. Evol. 33, 9-21.

Rijsewijk, F., Schuermann, M., Wagenaar, E., Parren, P., Weigel, D., Nusse, R., 1987. The Drosophila homologue of the mouse mammary oncogene int- 1 is identical to the segment polarity gene wingless. Cell 50, 649-657.

Roever, K., 1975. Megathymidae. In: Howe, W.H. (Ed.), The Butterflies of North America. Doubleday \& Co., Inc., Garden City, New York, pp. 411-422.

Scott, J.A., 1985. The phylogeny of butterflies (Papilionidae and Hesperioidea). J. Res. Lepidoptera 23, 241-281.

Scott, J.A., 2006. Notamblyscirtes new genus. In: Scott, J. (Ed.), Taxonomic studies and new taxa of North American butterflies. Papilio (new series) 12, 70.

Scott, J.A., Wright, D.M., 1990. Butterfly phylogeny and fossils. In: Kudrna, O. (Ed.), Butterflies of Europe. Vol. 2. Introduction to Lepidopterology. AULA Verlag, Wiesbaden, pp. 152-208.

Scudder, S.H., 1875. The two principal groups of Urbicolae (Hesperidae auct.). Bull. Buff. Soc. Nat. Sci. 1, 195-196.

Shirôzu, T., Saigusa, T., 1962. Butterflies collected by the Osaka City University Biological Expedition to southeast Asia 1957-58 (Part I). Nat. Life Southeast Asia 2, 25-94.

Sikes, D.S., Lewis, P.O., 2001. Beta Software, Version 1. PAUPRat: PAUP* Implementation of the Parsimony Ratchet. Distributed by the Authors. Department of Ecology and Evolutionary Biology, University of Connecticut, Storrs, USA.

Sorenson, M.D., 1999. TreeRot, Version 2. Boston University, Boston, MA.

Speyer, A., 1877. [Definitions of genera]. In: Edwards, W.H. (Ed.), Catalogue of the Diurnal Lepidoptera of America North of Mexico. Trans. Am. Entomol. Soc., 6, 1-68.

Stallings, D.B., Turner, J.R., 1958. A review of the Megathymidae of Mexico, with a synopsis of the classification of the family. Lepid. News 11, 113-137.

Stallings, D.B., Turner, J.R., 1959. The names for the suprageneric categories of the Megathymidae. Lepid. News 12, 93-94.

Stanford, R.E., 1981. Superfamily Hesperioidea, Latreille, 1802. In: Ferris, C.D., Brown, F.M. (Eds.), Butterflies of the Rocky Mountain States. University of Oklahoma Press, Norman, pp. $80-141$.

Steinhauser, S.R., 1974. Notes on Neotropical Nymphalidae and Hesperiidae with descriptions of new species and subspecies and a new genus. Bull. Allyn Mus. 22, 1-38.

Steinhauser, S.R., 1986. A review of the skippers of the narcosius group of species of the genus Astraptes Hubner (sensu Evans, 1952) and erection of a new genus. Lepidoptera: Hesperiidae. Bull. Allyn Mus. 104, 1-43.

Steinhauser, S.R., 1987. Notes on the identity of the species-group names in the genera Urbanus and Astraptes (sensu Evans). Bull. Allyn Mus. 111, 1-16.

Steinhauser, S.R., 1989. Taxonomic notes and descriptions of new taxa in the Neotropical Hesperiidae. Part I. Pyrginae. Bull. Allyn Mus. $127,1-70$.

Steinhauser, S.R., 1991. Taxonomic notes and descriptions of new taxa in the Neotropical Hesperiidae. Part II, Heteropterinae and Hesperiinae, Vinius group. Bull. Allyn Mus. 127, 1-70. 
Swinhoe, C., 1912-1913. In: Moore, F. Lepidoptera Indica. L. Reeve \& Co., London. Vol. IX, Vol. X.

Swofford, D.L., 2002. PAUP*: Phylogenetic Analysis Using Parsimony, Version 4.0b10. Sinauer Associates, Sunderland, MA.

Tsukiyama, H., 1985. Leon Croizat no Hanashi [On the biologist Leon Croizat; includes partial cladistic analysis of Bibasis]. Tsu i So 447, $125-133$.

Tutt, J.W., 1905-1914. Natural History of British Butterflies. Elliot Stock, London. 4 vols.

Tutt, J.W., 1906. Catalogue of the Palaearctic Urbicolides. Entomol. Record J. Var. 18, 195-198.

Vane-Wright, R.I., Jong, R. de., 2003. The butterflies of Sulawesi: annotated checklist for a critical island fauna. Zool. Verhandel. $343,1-267$.

Verity, R., 1940. Le Farfalle Diurne D'Italia. Volume Primero. Considerazioni Generali: Superfamiglia Hesperides. Casa Editrice Marzocco, S.A., Firenze, Italia.

Voss, E.G., 1952. On the classification of the Hesperiidae. Ann. Entomol. Soc. Am. 45, 246-258.

Wahlberg, N., Nylin, S., 2003. Morphology versus molecules: resolution of the positions of Nymphalis, Polygonia, and related genera (Lepidoptera: Nymphalidae). Cladistics 19, 213-223.

Wahlberg, N., Weingartner, E., Nylin, S., 2003. Towards a better understanding of the higher systematics of Nymphalidae (Lepidoptera: Papilionoidea). Mol. Phylogenet. Evol. 28, 473-484.

Wahlberg, N., Braby, M.F., Brower, A.V.Z., de Jong, R., Lee, M.M., Nylin, S., Pierce, N.E., Sperling, F.A.H., Vila, R., Warren, A.D., Zakharov, E., 2005a. Synergistic effects of combining morphological and molecular data in resolving the phylogeny of butterflies and skippers. Proc. R. Soc. B 272, 1577-1586.

Wahlberg, N., Brower, A.V.Z., Nylin, S., 2005b. Phylogenetic relationships and historical biogeography of tribes and genera in the subfamily Nymphalinae (Lepidoptera: Nymphalidae). Biol. J. Linn. Soc. 86, 227-251.

Warren, B.C.S., 1926. Monograph of the tribe Hesperiidi (European species) with revised classification of the subfamily Hesperiinae (Palaearctic species) based on the genital armature of the males. Trans. Entomol. Soc. Lond. 74, 1-170.

Warren, A.D., 1996. Phylogenetic Revision of the Skippers of the mithridates Species Group, and Their Replacement in Eantis Boisduval, 1836 (Lepidoptera: Hesperiidae: Pyrginae). Entomology Department Honors Thesis, Cornell University, Ithaca, NY.

Warren, A.D., 2000. Hesperioidea (Lepidoptera). In: Llorente Bousquets, J.E., González Soriano, E., Papavero, N. (Eds.), Biodiversidad, Taxonomía y Biogeografía de Artrópodos de México: Hacia una Síntesis de su Conocimiento, Vol. II. Universidad Nacional Autónoma de México, Mexico City, pp. 535-580.

Warren, A.D., 2001a. A new genus and species of Cyclopidinae from Zamora, Ecuador (Lepidoptera: Hesperiidae). Boletín Científico, Museo de Historia Natural, Universidad de Caldas 5, 138153.

Warren, A.D., 2001b. A replacement name for Freemania A. Warren, with notes on the higher classification of the genus (Lepidoptera: Hesperiidae). Proc. Entomol. Soc. Washington 103, 1028-1029.

Warren, A.D., 2004. Wingless to COI idenshi ni yoru seseri-cho-joka no kato kankei [The use of partial sequences from the wingless and COI genes to infer relationships among the Hesperioidea (Lepidoptera)]. Konchu to Shizen [Nature and Insects] 39, 1, 1116. [In Japanese]

Warren, A.D., 2006. The Higher Classification of the Hesperiidae. $\mathrm{PhD}$ Dissertation, Oregon Sate University, Corvallis.

Waterhouse, G.A., 1932. What Butterfly is That? Angus and Robertson, Sydney.

Watson, E.Y., 1893. A proposed classification of the Hesperiidae, with a revision of the genera. Proc. Zool. Soc. Lond. 1893, 3-132.
Weller, S.J., Pashley, D.P., Martin, J.A., Constable, J.L., 1994. Phylogeny of noctuoid moths and the utility of combining independent nuclear and mitochondrial genes. Syst. Biol. 43, 194-211.

Wiegmann, B.M., Mitter, C., Regier, J.C., Friedlander, T.P., Wagner, D.M., Nielsen, E.S., 2000. Nuclear genes resolve Mesozoic-aged divergences in the insect order Lepidoptera. Mol. Phylogenet. Evol. $15,242-259$

\section{Appendix 1}

\section{Hesperiidae genera of the world}

The arrangement of the Coeliadinae follows Evans (1937, 1949), Tsukiyama (1985), Maruyama (1991), Ackery et al. (1995), Chiba (1995, 1997) and VaneWright and de Jong (2003); the arrangement of the Pyrrhopyginae follows Evans (1951) and Mielke (1995, 2001, 2002, 2004, 2005); the arrangement of the Pyrginae follows Evans $(1937,1949,1952,1953)$, Shirôzu and Saigusa (1962), Freeman (1969a), Mielke (1977, 2004, 2005), de Jong (1982), Steinhauser (1986, 1989), Ackery et al. (1995), Burns (1996, 1999), Warren (1996, 2000), Austin (1997), Austin and Warren (2001), Burns and Janzen (2005) and Larsen (2005); the status and arrangement of the Heteropterinae follows Higgins (1976), Warren (2000, 2001a,b), Mielke (2004, 2005), and Larsen (2005); the arrangement of the Trapezitinae follows Atkins (1973, 1984, 1994), Mayo and Atkins (1992), Atkins and Edwards (1996), Parsons (1999), and Braby $(2000,2004)$; the arrangement of the Hesperiinae follows Evans (1937, 1949, 1955), Lindsey and Miller (1965), Miller (1965), Mielke (1968, 1980, 1992), Steinhauser (1974, 1991), Eliot (1978- in part), de Jong (1983), Maruyama (1991), Burns (1992a,b, 1994a,b), Bridges (1993), de Jong and Treadaway (1993), Chiba and Tsukiyama (1994), Ackery et al. (1995), Devyatkin (1996, 2002), Austin (1997), Austin and DeVries (2001), Mielke and Casagrande (2002, 2003), Vane-Wright and de Jong (2003), Larsen (2005), Scott (2006), and Fan et al. (2007); the status and arrangement of the Megathyminae follows Freeman (1969b) and Mielke (2004, 2005), but see Ackery et al. (1999) and Opler and Warren (2002).

Genera represented in this study are listed in bold. Genera preceded with an asterisk were not included in the final combined analysis, but were included in alternative analyses, and are discussed in the text.

COELIADINAE

Bibasis Moore, 1881

Burara Swinhoe, 1893

Allora Waterhouse \& Lyell, 1914

Hasora Moore, 1881

Badamia Moore, 1881

Choaspes Moore, 1881 
Coeliades Hübner, [1818]

Pyrrhiades Lindsey \& Miller, 1965

Pyrrhochalcia Mabille, 1904

PYRRHOPYGINAE

OXYNETRINI

Oxynetra C. Felder \& R. Felder, 1862

Cyclopyge Mielke, 2002

PYRRHOPYGINI

Pyrrhopyge Hübner, 1819

* Yanguna Watson, 1893

Gunayan Mielke, 2002

Chalypyge Mielke, 2002

Ochropyge Mielke, 2002

Apyrrhothrix Lindsey, 1921

Melanopyge Mielke, 2002

Jonaspyge Mielke, 2002

Creonpyge Mielke, 2002

Cyanopyge Mielke, 2002

Elbella Evans, 1951

Parelbella Mielke, 1995

Pseudocroniades Mielke, 1995

Protelbella Mielke, 1995

Nosphistia Mabille \& Boullet, 1908

*Jemadia Watson, 1893

* Mimoniades Hübner, 1823

Mimardaris Mielke, 2002

Ardaris Watson, 1893

Amenis Watson, 1893

Sarbia Watson, 1893

Metardaris Mabille, 1903

Amysoria Mielke, 2002

Mysoria Watson, 1893

Mysarbia Mielke, 2002

Microceris Watson, 1893

Croniades Mabille, 1903

\section{ZONIINI}

Zonia Evans, 1951

PASSOVINI

Azonax Godman \& Salvin, 1893

Myscelus Hübner, 1819

Granila Mabille, 1903

Passova Evans, 1951

Aspitha Evans, 1951

\section{PYRGINAE}

$\overline{\text { EUDAMINI }}$

Augiades Group

Phocides Hübner, 1819

Hypocryptothrix Watson, 1893

Tarsoctenus Watson, 1893

Phanus Hübner, 1819

Udranomia Butler, 1870

Drephalys Watson, 1893

Augiades Hübner, 1819

Hyalothyrus Mabille, 1878

Phareas Westwood, 1852

Entheus Hübner, 1819

Cabirus Hübner, 1819

Urbanus Group

Proteides Hübner, 1819

Epargyreus Hübner, 1819

Polygonus Hübner, 1825
Chioides Lindsey, 1921

Aguna Williams, 1927

Cephise Evans, 1952

Typhedanus Butler, 1870

Polythrix Watson, 1893

Heronia Mabille \& Boullet, 1912

Chrysoplectrum Watson, 1893

Zestusa Lindsey, 1925

Codatractus Lindsey, 1921

Ridens Evans, 1952

Urbanus Hübner, 1807

Astraptes Hübner, 1819

Narcosius Steinhauser, 1986

Calliades Mabille \& Boullet, 1912

Autochton Hübner, 1823

Achalarus Scudder, 1872

Thessia Steinhauser, 1989

Venada Evans, 1952

Thorybes Scudder, 1872

Cabares Godman \& Salvin, 1894

Celaenorrhinus Group

"Old World" Subgroup

Euschemon Doubleday, 1846

Chaetocneme C. Felder, 1860

Capila Moore, 1866

Lobocla Moore, 1884

Celaenorrhinus Group

Bungalotis Subgroup

Bungalotis Watson, 1893

Salatis Evans, 1952

Sarmientoia Berg, 1897

Dyscophellus Godman \& Salvin, 1893

Celaenorrhinus Group

Nascus Subgroup

Nascus Watson, 1893

Celaenorrhinus Group

Porphyrogenes Subgroup

Porphyrogenes Watson, 1893

Ocyba Lindsey, 1925

Oileides Hübner, 1825

Celaenorrhinus Group

Celaenorrhinus Subgroup

Katreus Watson, 1893

Loxolexis Karsch, 1895

Celaenorrhinus Hübner, 1819

Aurina Evans, 1937

PYRGINI

Tagiades Group

Netrocoryne Subgroup

Netrocoryne C. Felder \& R. Felder, 1867

Tapena Moore, 1881

Darpa Moore, 1866

Odina Mabille, 1891

Coladenia Moore, 1881

Pseudocoladenia Shirôzu \& Saigusa, 1962

Eagris Guénée, 1863

Calleagris Aurivillius, 1925

Procampta Holland, 1892 
Eretis Mabille, 1891

Sarangesa Moore, 1881

Tagiades Group

Tagiades Subgroup

Satarupa Moore, 1866

Seseria Matsumura, 1919

Pintara Evans, 1932

Chamunda Evans, 1949

Daimio Murray, 1875

*Gerosis Mabille, 1903

Tagiades Hübner, 1819

Mooreana Evans, 1926

Abraximorpha Elwes \& Edwards, 1897

Exometoeca Meyrick, 1888

Tagiades Group

Caprona Subgroup

Ctenoptilum de Nicéville, 1890

* Odontoptilum de Nicéville, 1890

Netrobalane Mabille, 1903

Caprona Wallengren, 1857

Leucochitonea Wallengren, 1857

Abantis Hopffer, 1885

Telemiades Group

Telemiades Subgroup

Spathilepia Butler, 1870

Oechydrus Watson, 1893

Jera Lindsey, 1925

Marela Mabille, 1903

Cogia Butler, 1870

Paracogia Mielke, 1977

Telemiades Hübner, 1819

Mimia Evans, 1953

Ectomis Mabille, 1878

Nerula Mabille, 1888

Telemiades Group

Nisoniades Subgroup

Conognathus C. Felder \& R. Felder 1862

Arteurotia Butler \& H. Druce, 1872

Pseudodrephalys Burns, 1999

Eracon Godman \& Salvin, 1894

Cornuphallus Austin, 1997

Spioniades Hübner, 1819

Mictris Evans, 1955

Iliana Bell, 1937

Sophista Plötz, 1879

Polyctor Evans, 1953

Nisoniades Hübner, 1819

Pachyneuria Mabille, 1888

Pellicia Herrich-Schäffer, 1870

Noctuana Bell, 1937

Windia Freeman, 1969a

Morvina Evans, 1953

Myrinia Evans, 1953

Xispia Lindsey, 1925

Ocella Evans, 1953

Cyclosemia Mabille, 1878

Gorgopas Godman \& Salvin, 1894

Telemiades Group

Staphylus Subgroup
Viola Evans, 1953

Burca Bell \& Comstock, 1948

Bolla Mabille, 1903

Staphylus Godman \& Salvin, 1896

Plumbago Evans, 1953

Trina Evans, 1953

Diaeus Godman \& Salvin, 1895

Telemiades Group

Quadrus Subgroup

Gorgythion Godman \& Salvin, 1896

Ouleus Lindsey, 1925

Zera Evans, 1953

Quadrus Lindsey, 1925

Telemiades Group

Pythonides Subgroup

Gindanes Godman \& Salvin, 1895

Pythonides Hübner, 1819

Sostrata Godman \& Salvin, 1895

Paches Godman \& Salvin, 1895

Telemiades Group

Paramimus Subgroup

Haemactis Mabille, 1903

Atarnes Godman \& Salvin, 1897

Milanion Godman \& Salvin, 1895

Paramimus Hübner, 1819

Charidia Mabille, 1903

Telemiades Group

Antigonus Subgroup

Potamanaxas Lindsey, 1925

Mylon Godman \& Salvin, 1894

Carrhenes Godman \& Salvin, 1895

Zobera Freeman, 1970

Clito Evans, 1953

* Xenophanes Godman \& Salvin, 1895

Onenses Godman \& Salvin, 1895

Antigonus Hübner, 1819

Systasea Edwards, 1877

Timochreon Godman \& Salvin, 1896

Zopyrion Godman \& Salvin, 1896

Anisochoria Mabille, 1876

Erynnis Group

Aethilla Hewitson, 1868

Achlyodes Hübner, 1819

Eantis Boisduval, 1836

Grais Godman \& Salvin, 1894

Doberes Godman \& Salvin, 1895

Timochares Godman \& Salvin, 1896

Anastrus Hübner, 1824

Tosta Evans, 1953

Ebrietas Godman \& Salvin, 1896

Helias Fabricius, 1807

Camptopleura Mabille, 1877

Cycloglypha Mabille, 1903

Theagenes Godman \& Salvin, 1896

Chiomara Godman \& Salvin, 1899

Gesta Evans, 1953

Ephyriades Hübner, 1819

Erynnis Schrank, 1801 
Pyrgus Group

Gomalia Moore, 1879

Carcharodus Hübner, 1819

Spialia Swinhoe, 1912

Muschampia Tutt, 1906

Alenia Evans, 1935

Pyrgus Hübner, 1819

Heliopyrgus Herrera, 1957

Heliopetes Billberg, 1820

Pholisora Scudder, 1872

Hesperopsis Dyar, 1905

Celotes Godman \& Salvin, 1899

HETEROPTERINAE

Hovala Evans, 1937

Metisella Hemming, 1934

*Tsitana Evans, 1937

Lepella Evans, 1937

Leptalina Mabille, 1904

Carterocephalus Lederer, 1852

Heteropterus Duméril, 1806

Barca de Nicéville, 1902

Apostictopterus Leech, 1893

Piruna Evans, 1955

Dardarina Evans, 1937

Butleria Kirby, 1871

Argopteron Watson, 1893

Dalla Mabille, 1904

Freemaniana A. Warren, $2001 \mathrm{~b}$

\section{TRAPEZITINAE}

Felicena Waterhouse, 1932

Trapezites Hübner, 1819

*Anisynta Lower, 1911

*Pasma Waterhouse, 1932

Dispar Waterhouse \& Lyell, 1914

*Neohesperilla Waterhouse \& Lyell, 1914

Hewitsoniella Shepard, 1931

Toxidia Mabille, 1891

Signeta Waterhouse \& Lyell, 1914

Oreisplanus Waterhouse \& Lyell, 1914

Hesperilla Hewitson, 1868

Motasingha Watson, 1893

Antipodia Atkins, 1984

Proeidosa Atkins, 1973

Croitana Waterhouse, 1932

Herimosa Atkins, 1994

Mesodina Mayrick, 1901

Rachelia Hemming, 1964

\section{HESPERIINAE}

Astictopterus Group

Astictopterus Subgroup

Astictopterus C. Felder \& R. Felder, 1860

Arnetta Watson, 1893

Astictopterus Group

Ampittia Subgroup

Ochus de Nicéville, 1894

Baracus Moore, 1881

Aeromachus de Nicéville, 1890

Prosopalpus Holland, 1896

Ampittia Moore, 1881

Kedestes Watson, 1893

Fulda Evans, 1937
Galerga Mabille, 1898

Gorgyra Holland, 1896

Gyrogra Lindsey \& Miller, 1965

Astictopterus Group

Halpe Subgroup

Sebastonyma Watson, 1893

Sovia Evans, 1949

Parasovia Devyatkin, 1996

Pedesta Hemming, 1934

Onryza Watson, 1893

Thoressa Swinhoe, 1913

Halpe Moore, 1878

Pithauria Moore, 1878

Isoteinon Group

Isoteinon C. Felder \& R. Felder, 1862

Actinor Watson, 1893

Eogenes Mabille, 1909

Ceratrichia Group

Teniorhinus Holland, 1892

Ceratrichia Butler, 1870

Pardaleodes Butler, 1870

Ankola Evans, 1937

Xanthodisca Aurivillius, 1925

Acada Evans, 1937

Parosmodes Holland, 1896

Rhabdomantis Holland, 1896

Osmodes Holland, 1892

Osphantes Holland, 1896

Acleros Group

Paracleros Berger, 1896

Acleros Mabille, 1885

Semalea Holland, 1896

Hypoleucis Mabille, 1891

Meza Hemming, 1939

Paronymus Aurivillius, 1925

Andronymus Holland, 1896

Ploetzia Group

Malaza Mabille, 1904

Miraja Evans, 1937

Perrotia Oberthür, 1916

Ploetzia Saalmüller, 1884

Moltena Evans, 1937

Chondrolepis Mabille, 1904

Zophopetes Mabille, 1904

Gamia Holland, 1896

Artitropa Holland, 1896

Mopala Evans, 1937

*Gretna Evans, 1937

*Pteroteinon Watson, 1893

Leona Evans, 1937

Caenides Holland, 1896

Monza Evans, 1937

Ancistroides Group

Iambrix Watson, 1893

Idmon de Nicéville, 1895

*Koruthaialos Watson, 1893

Psolos Staudinger, 1889 
Stimula de Nicéville, 1898

Ancistroides Butler, 1874

*Notocrypta de Nicéville, 1889

Udaspes Moore, 1881

Plastingia Group

Plastingia Subgroup

Praescobura Devyatkin, 2002

Scobura Elwes \& Edwards, 1897

Suada de Nicéville, 1895

Suastus Moore, 1881

Cupitha Moore, 1884

Zographetus Watson, 1893

Oerane Elwes \& Edwards, 1897

Hyarotis Moore, 1881

Quedara Swinhoe, 1919

Isma Distant, 1886

Xanthoneura Eliot, 1978

Plastingia Butler, 1870

Salanoemia Eliot, 1978

* Pemara Eliot, 1978

*Pyroneura Eliot, 1978

Pseudokerana Eliot, 1978

Lotongus Distant, 1886

Plastingia Group

Erionota Subgroup

Zela de Nicéville, 1895

Gangara Moore, 1881

Erionota Mabille, 1878

Ilma Swinhoe, 1905

Ge de Nicéville, 1895

Matapa Moore, 1881

Pudicitia de Nicéville, 1895

Plastingia Group

Unkana Subgroup

Unkana Distant, 1886

Hidari Distant, 1886

Eetion de Nicéville, 1895

Acerbas de Nicéville, 1895

Pirdana Distant, 1886

Pseudopirdana Chiba \& Tsukiyama, 1994

Creteus de Nicéville, 1895

Plastingia Group

Prada Subgroup

Prada Evans, 1949

Tiacellia Evans, 1949

Vinius Group

Falga Mabille, 1898

Synapte Mabille, 1904

Lento Evans, 1955

Levina Evans, 1955

Zariaspes Godman, 1900

Anthoptus Bell, 1942

Corticea Evans, 1955

Zalomes Bell, 1947

Wahydra Steinhauser, 1991

Cantha Evans, 1955

Vinius Godman, 1900

Vinpeius Austin, 1997

Pheraeus Godman, 1900
Misius Evans, 1955

Molo Godman, 1900

Racta Evans, 1955

Pyrrhocalles Mabille, 1904

Apaustus Group

Apaustus Subgroup

Apaustus Hübner, 1819

Callimormus Scudder, 1872

Radiatus Mielke, 1968

Peba Mielke, 1968

Eutocus Godman, 1901

Virga Evans, 1955

Eprius Godman, 1901

Mnasicles Godman, 1901

Ludens Evans, 1955

Methionopsis Godman, 1901

Panca Evans, 1955

Sodalia Evans, 1955

Mnestheus Godman, 1901

Artines Godman, 1901

Flaccilla Godman, 1901

Mnaseas Godman, 1901

Inglorius Austin, 1997

Apaustus Group

Phanes Subgroup

Gallio Evans, 1955

Methion Godman, 1900

Thargella Godman, 1900

Venas Evans, 1955

Pamba Evans, 1955

Saniba Mielke \& Casagrande, 2003

Repens Evans, 1955

Lucida Evans, 1955

Phanes Godman, 1901

Apaustus Group

Cymaenes Subgroup

Vidius Evans, 1955

Igapophilus Mielke, 1980

Monca Evans, 1955

Nastra Evans, 1955

Cymaenes Scudder, 1872

Vehilius Godman, 1900

Mnasilus Godman, 1900

Sucova Evans, 1955

Mnasinous Godman, 1900

Mnasitheus Godman, 1900

Moeris Godman, 1900

Remella Hemming, 1939

*Parphorus Godman, 1900

Apaustus Group

Lerema Subgroup

Molla Evans, 1955

Papias Godman, 1900

Propapias Mielke, 1992

Cobalopsis Godman, 1900

Arita Evans, 1955

Lerema Scudder, 1872

Morys Godman, 1900

Cumbre Evans, 1955

Adlerodea Hayward, 1940 
Psoralis Mabille, 1904

Tigasis Godman, 1900

Eutychide Godman, 1900

Onophas Godman, 1900

Apaustus Group

Vettius Subgroup

Vettius Godman, 1901

Paracarystus Godman, 1900

Turesis Godman, 1901

Thoon Godman, 1900

Justinia Evans, 1955

Lamponia Evans, 1955

Naevolus Hemming, 1939

Carystus Group

Miltomiges Mabille, 1903

Styriodes Schaus, 1913

Dion Godman, 1901

Enosis Mabille, 1889

Vertica Evans, 1955

Ebusus Evans, 1955

Evansiella Hayward, 1948

Argon Evans, 1955

Cobaloides Hayward, 1939

Sacrator Evans, 1955

Megaleas Godman, 1901

Lychnuchus Hübner, 1831

Talides Hübner, 1819

Tromba Evans, 1955

Nyctus Mabille, 1891

Turmada Evans, 1955

Synale Mabille, 1904

Carystus Hübner, 1819

Telles Godman, 1900

Tisias Godman, 1901

Moeros Evans, 1955

Cobalus Hübner, 1819

Dubiella Evans, 1936

Carystina Evans, 1955

Tellona Evans, 1955

Damas Godman, 1901

Orphe Godman, 1901

Carystoides Godman, 1901

Lychnuchoides Godman, 1901

Perichares Scudder, 1872

Orses Godman, 1901

Alera Mabille, 1891

Lycas Godman, 1901

Phlebodes Group

Phlebodes Subgroup

Saturnus Evans, 1955

Phlebodes Hübner, 1819

Joanna Evans, 1955

Punta Evans, 1955

Bruna Evans, 1955

Quinta Evans, 1955

Cynea Evans, 1955

Rhinthon Godman, 1900

*Mucia Godman, 1900

Penicula Evans, 1955

Phlebodes Group

Oeonus Subgroup
Decinea Evans, 1955

Oeonus Godman, 1900

Cyclosma Draudt, 1923

Caligulana Bell, 1942

Orthos Evans, 1955

Conga Evans, 1955

Holguinia Evans, 1955

Hesperia Group

Thymelicus Subgroup

Ancyloxypha C. Felder, [1863]

Oarisma Scudder, 1872

Copaeodes Speyer, 1877

Adopaeoides Godman, 1900

Thymelicus Hübner, 1819

Hesperia Group

Hesperia Subgroup

Hylephila Billberg, 1820

Pseudocopaeodes Skinner \& Williams, 1923

Stinga Evans, 1955

Hesperia Fabricius, 1793

Appia Evans, 1955

Linka Evans, 1955

Polites Scudder, 1872

Wallengrenia Berg, 1897

Pompeius Evans, 1955

Atalopedes Scudder, 1872

Atrytone Scudder, 1872

Problema Skinner \& Williams, 1924

Ochlodes Scudder, 1872

Neochlodes Austin \& DeVries, 2001

Buzyges Godman, 1900

Onespa Steinhauser, 1974

Poanes Scudder, 1872

Paratrytone Godman, 1900

Choranthus Scudder, 1872

Parachoranthus Miller, 1965

Anatrytone Dyar, 1905

Quasimellana Burns, 1994a

Librita Evans, 1955

Hesperia Group

Phemiades Subgroup

Euphyes Scudder, 1872

Arotis Mabille, 1904

Libra Evans, 1955

Hansa Evans, 1955

Chalcone Evans, 1955

Serdis Mabille, 1904

Metron Godman, 1900

Propertius Evans, 1955

Phemiades Hübner, 1819

Asbolis Mabille, 1904

Lerodea Group

Atrytonopsis Godman, 1900

Amblyscirtes Scudder, 1872

Notamblyscirtes Scott, 2006

*Lerodea Scudder, 1872

Oligoria Scudder, 1872

Calpodes Group

Calpodes Subgroup 
Calpodes Hübner, 1819

Panoquina Hemming, 1934

Zenis Godman, 1900

Tirynthoides Bell, 1940

Calpodes Group

Niconiades Subgroup

Tirynthia Godman, 1900

Nyctelius Hayward, 1948

Thespieus Godman, 1900

Vacerra Godman, 1900

Jongiana Mielke \& Casagrande, 2002

Lindra Evans, 1955

Oxynthes Godman, 1900

Niconiades Hübner, 1821

*Halotus Godman, 1900

Calpodes Group

Aides Subgroup

Aides Billberg, 1820

*Xeniades Godman, 1900

Cravera de Jong, 1983

Calpodes Group

Thracides Subgroup

Saliana Evans, 1955

Thracides Hübner, 1819

Neoxeniades Hayward, 1938

Aroma Evans, 1955

Calpodes Group

Chloeria Subgroup

Chloeria Mabille, 1904

Calpodes Group

Pseudosarbia Subgroup

Pyrrhopygopsis Godman, 1901

Pseudosarbia Berg, 1897

Taractrocera Group

Taractrocera Butler, 1870

Ocybadistes Heron, 1894
Suniana Evans, 1934

Oriens Evans, 1932

Potanthus Scudder, 1872

Arrhenes Mabille, 1904

Telicota Moore, 1881

Cephrenes Waterhouse \& Lyell, 1914

Pastria Evans, 1949

Banta Evans, 1949

Kobrona Evans, 1935

Sabera Swinhoe, 1908

Mimene Joicey \& Talbot, 1917

Gegenes Group

Prusiana Evans, 1937

Melphina Evans, 1937

Fresna Evans, 1937

Platylesches Holland, 1896

Brusa Evans, 1937

Zenonia Evans, 1935

Gegenes Hübner, 1819

Parnara Moore, 1881

Borbo Evans, 1949

Pelopidas Walker, 1870

Polytremis Mabille, 1904

Baoris Moore, 1881

*Caltoris Swinhoe, 1893

Iton de Nicéville, 1895

MEGATHYMINAE

MEGATHYMINI

Megathymus Scudder, 1872

Stallingsia Freeman, 1959

AEGIALINI

Aegiale C. Felder \& R. Felder, 1860

Turnerina Freeman, 1959

AGATHYMINI

Agathymus Freeman, 1959

FOSSIL GENERA

Pamphilites Scudder, 1875

Thanatites Scudder, 1875 


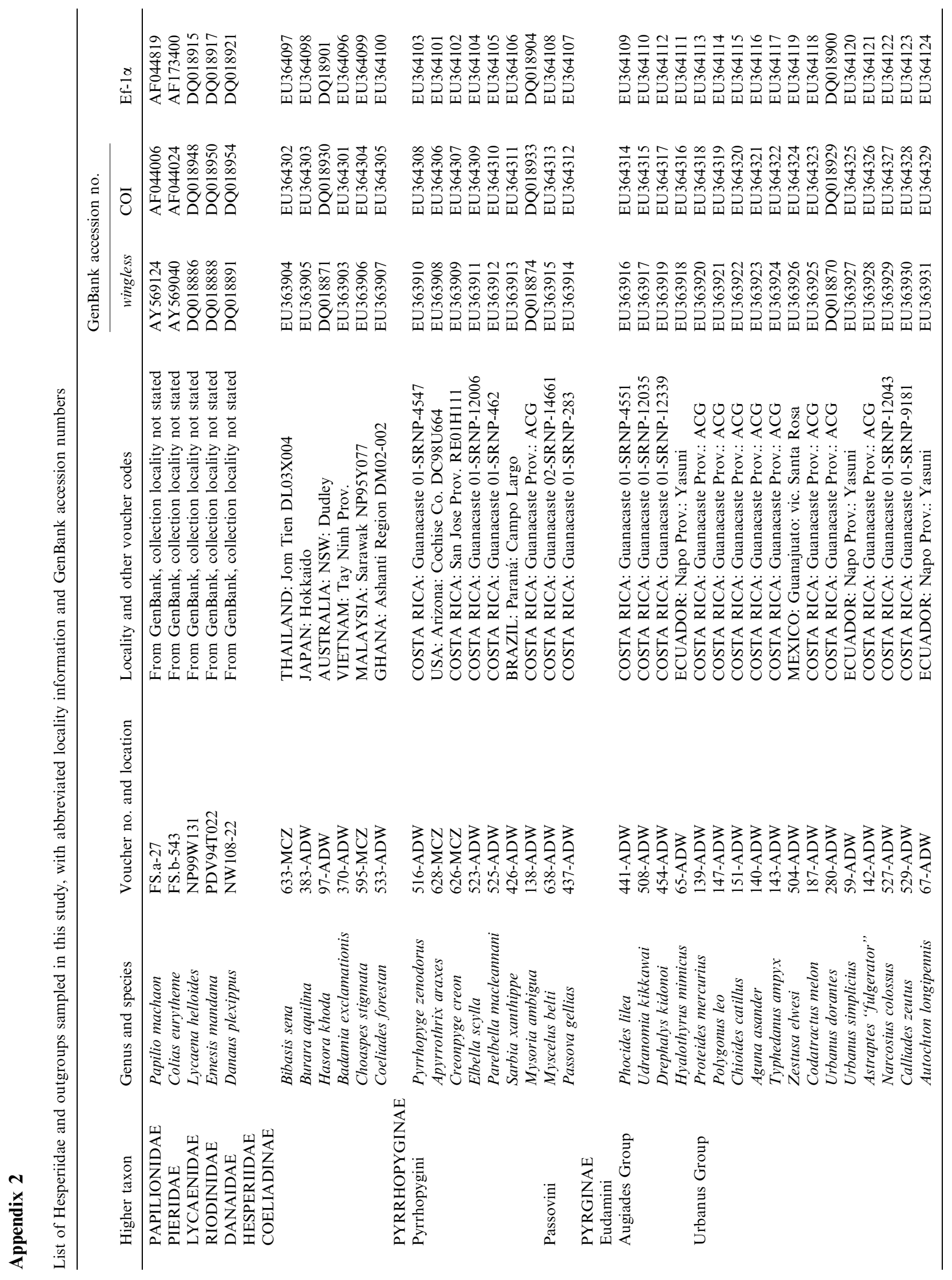




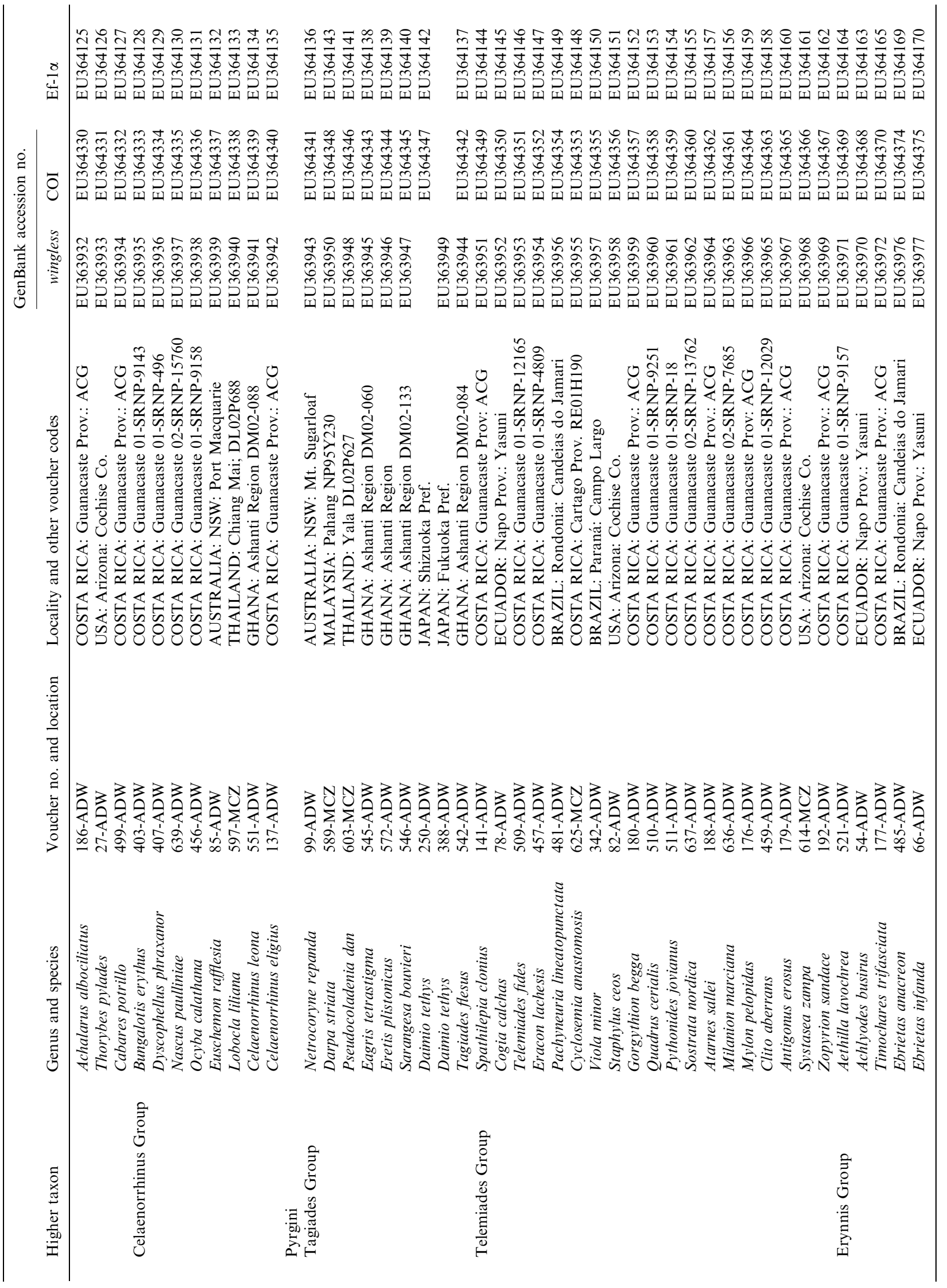




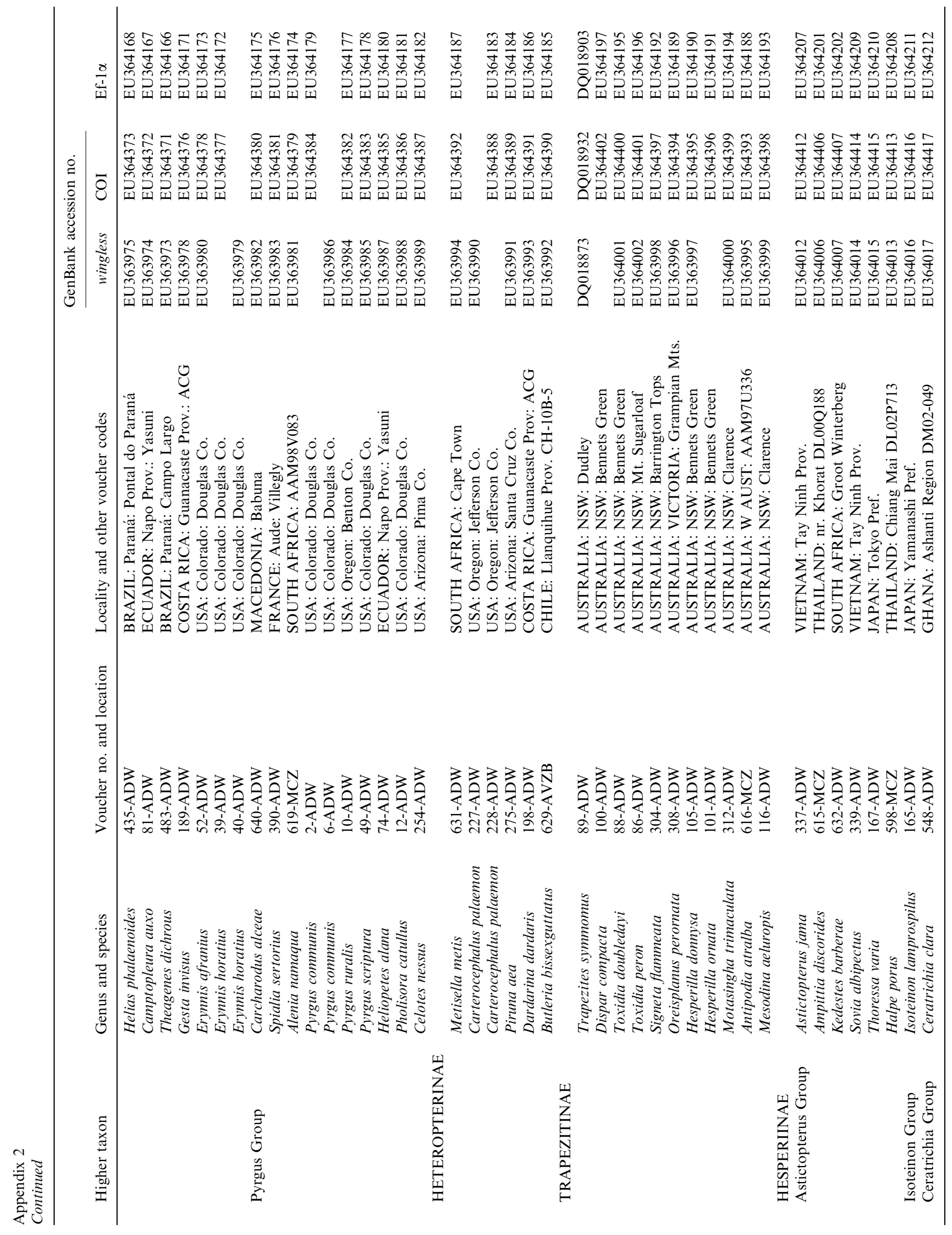


$\frac{8}{1}$

官

幽

8

迎

亏

离

च

?

๑ొ

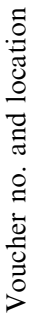

窟

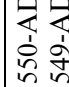

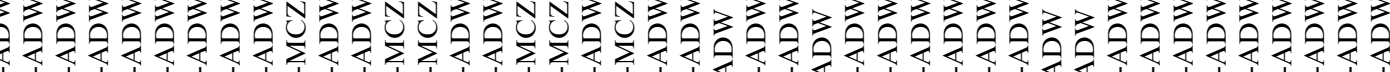

范

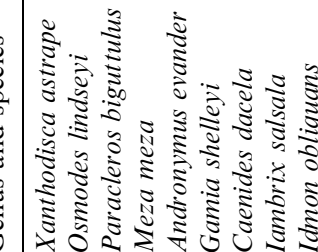

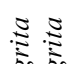

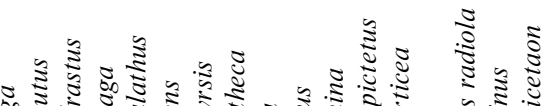

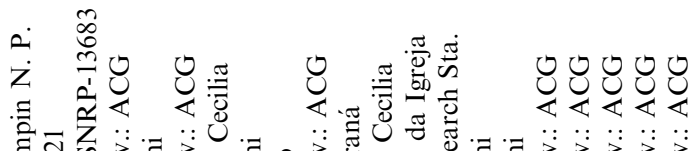

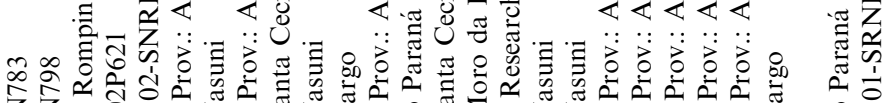

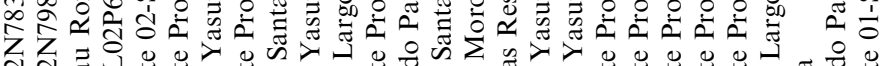

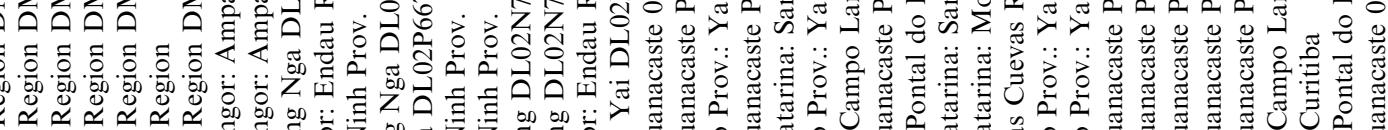

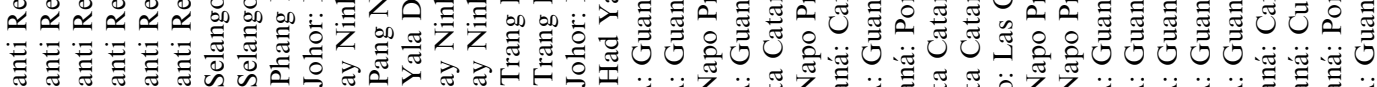

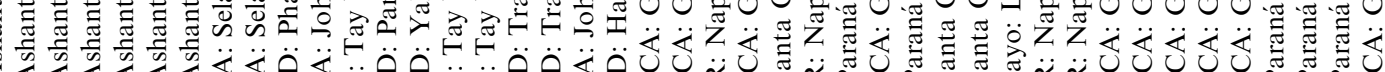

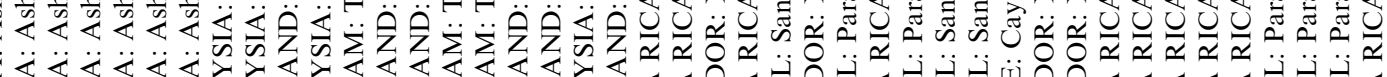

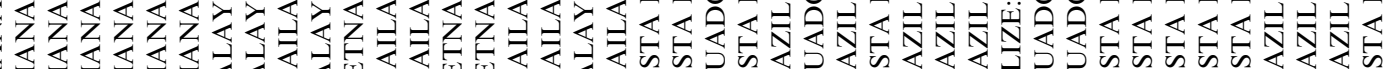

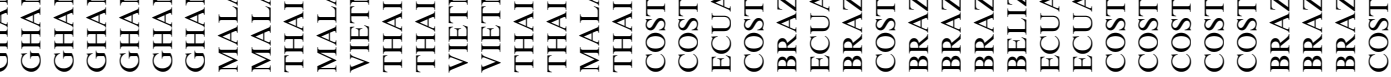

4

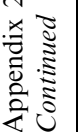

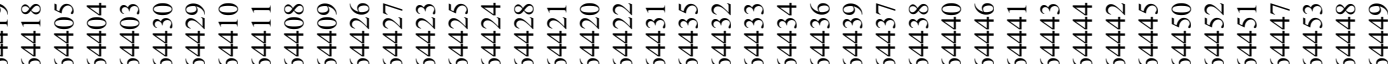

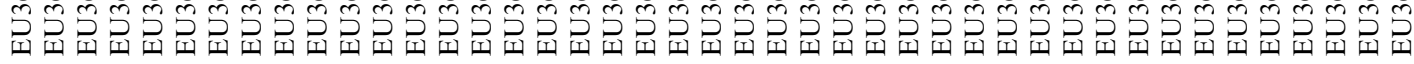

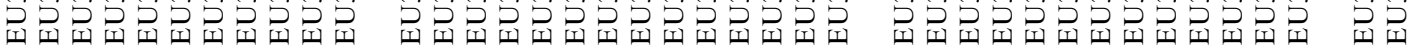

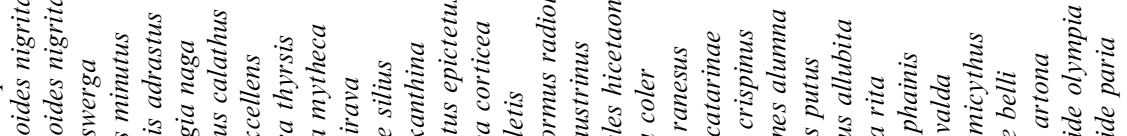

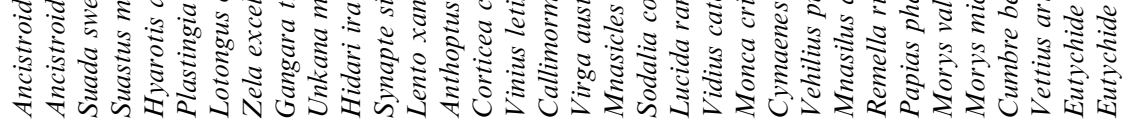

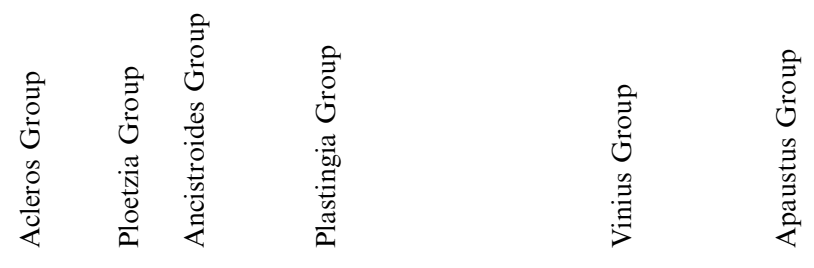

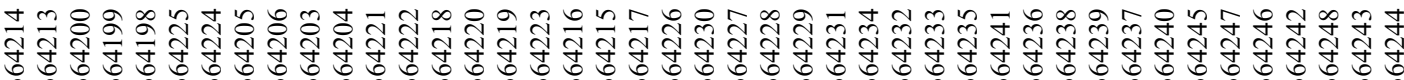




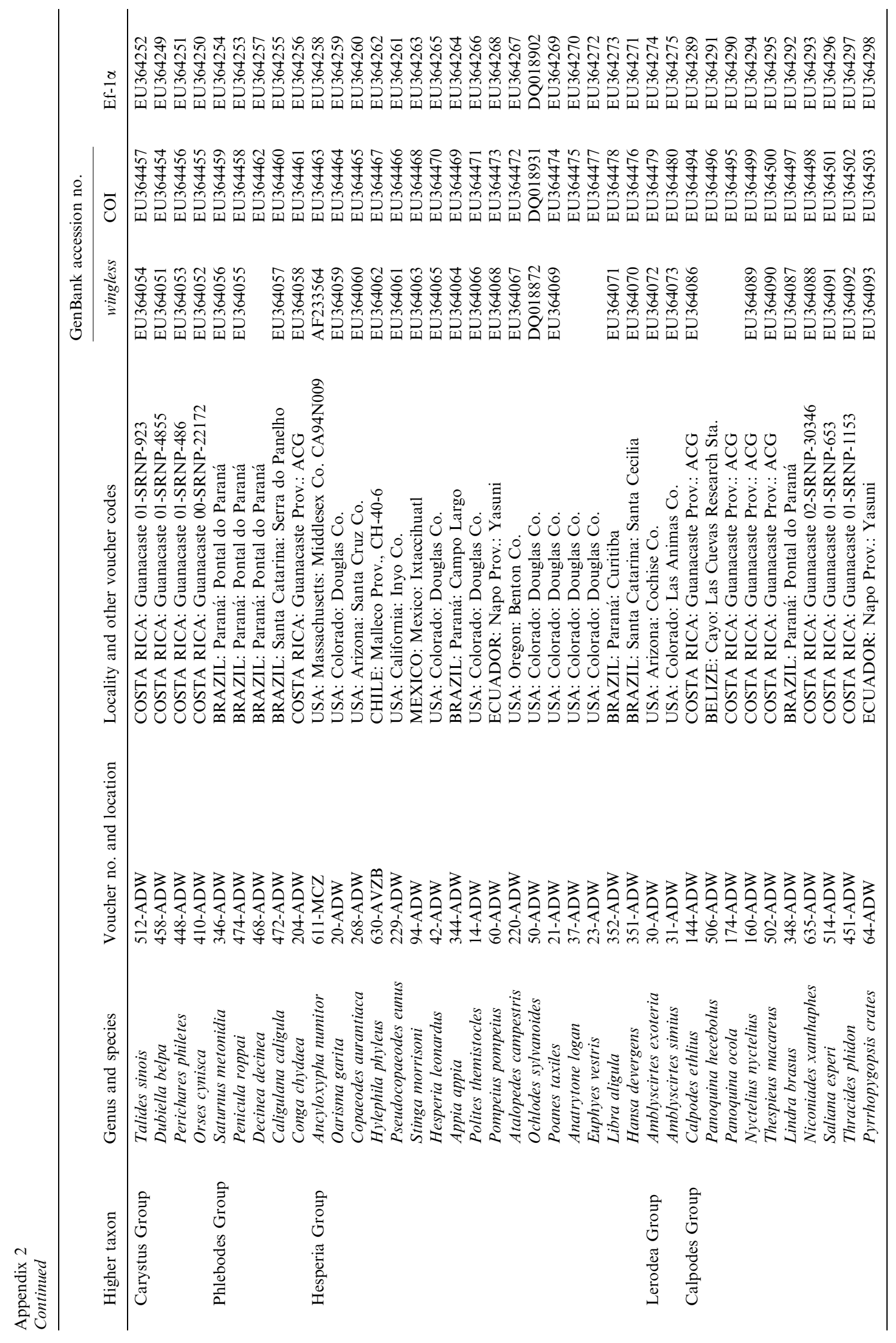




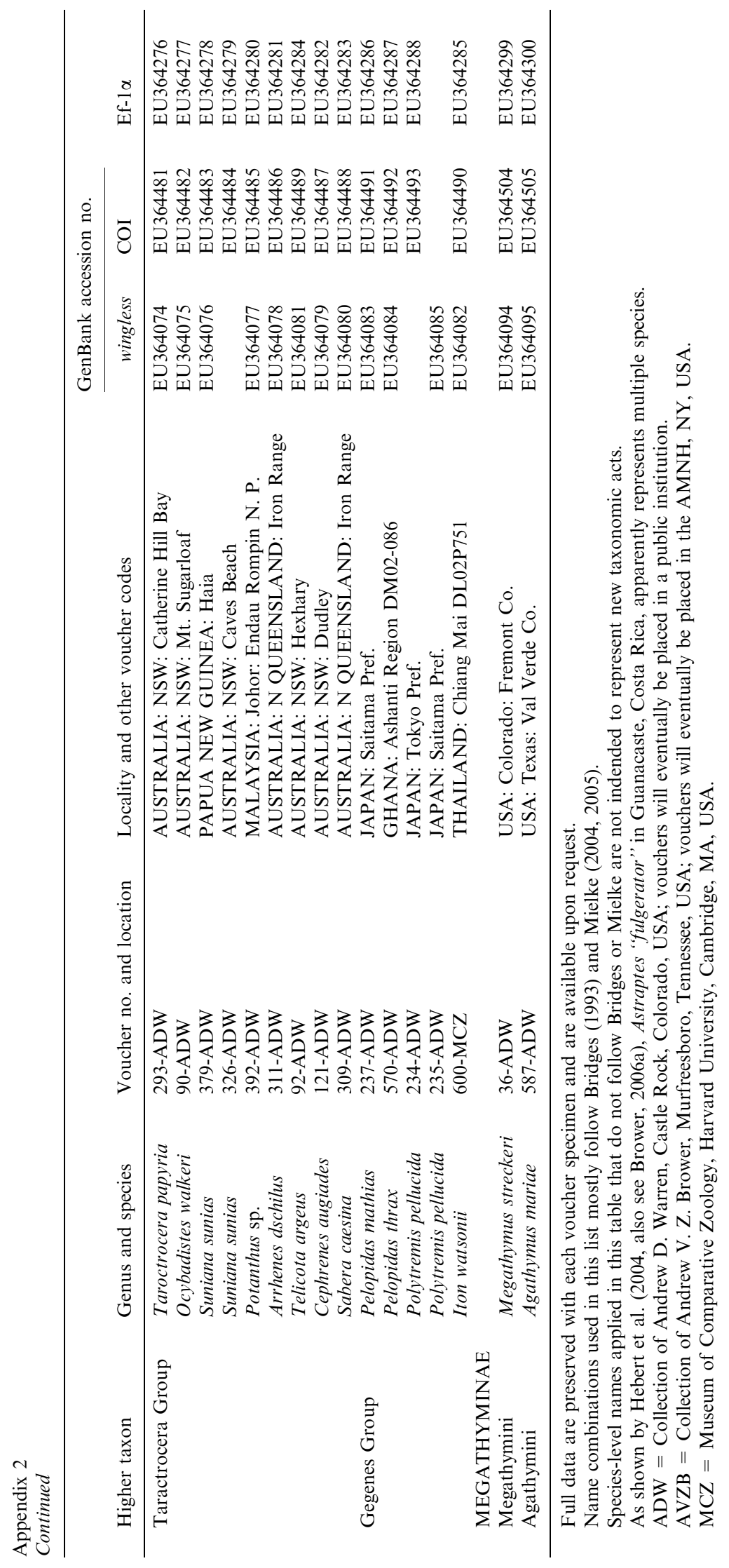

